Primljeno: 1.3 .2020 .

Prihvaćeno: 16.7.2020.

DOI: $10.36506 /$ av.63.8

\author{
Siniša Lajnert \\ Hrvatski državni arhiv \\ Zagreb, Hrvatska \\ slajnert@arhiv.hr
}

\title{
PRILOG POZNAVANJU HISTORIJATA BALKANSKE BANKE D.D. ZAGREB (1922.-1925./1948.)
}

UDK: 336.712(497.521.2Zagreb)“1922/1948“

Izvorni znanstveni rad

U članku se daje prilog poznavanju povijesti Balkanske banke d.d. Zagreb od njezina osnutka (1922.) pa sve do formalnoga završetka njezine likvidacije (1948.). Poslovanje banke razvijalo se je u početku izuzetno povoljno. U kolovozu 1922. predsjednik banke Dušan Plavšić pozvan je na dužnost pomoćnika ministra financija. Kako je vlada kojoj je Plavšić pripadao u prosincu 1922. dala ostavku, uslijed tadašnjih političkih prilika nastala je novinska kampanja koja je bila uperena i protiv Balkanske banke. Time je taj slučaj dobio i čisto političku konotaciju. Tada je počela propast Balkanske banke. Kontinuiranim napadima novoga ministra financija, radikala Milana Stojadinovića, na Dušana Plavsića, novinskom kampanjom protiv Plavšica i Balkanske banke te katastrofalno izvedenim devizno-čekounim transakcijama, cjelokupno poslovanje Balkanske banke došlo je u vrlo tešku financijsku situaciju. Krajem 1924. banci je odobrena prinudna nagodba. Na temelju te nagodbe banka je na svojoj izvanrednoj glavnoj skupśtini 1925. zaključila likvidaciju. Banka je pravno postojala sve do 1948., kada je nakon praktično formalizirane likvidacije brisana iz trgovačkoga registra Okružnoga suda za grad Zagreb.

Ključne riječi: Balkanska banka; novčarski zavod; bankovno poslovanje; Dušan Plavšić 


\section{Uvod}

U članku su prikazani rezultati istraživanja ustroja, kratkoga poslovanja te likvidacije Balkanske banke d.d. Zagreb (1922.-1925./1948.). Članak se temelji prvenstveno na analizi dostupnoga arhivskoga gradiva koje se nalazi u Hrvatskom državnom arhivu i Državnom arhivu u Zagrebu. Arhivski fondovi korišteni u ovom radu su: HR-HDA-152. Savska financijska direkcija (1929-1939), HRHDA-215. Ministarstvo državne riznice Nezavisne Države Hrvatske (1941-1945), HR-HDA-620. Služba likvidacije starih poslova centrale Narodne banke Jugoslavije u Zagrebu (1946-1972), HR-HDA-757. Obitelj Plavšić i HR-DAZG-1249. Balkanska banka d.d. Zagreb (1922-1947). Osim analize arhivskih fondova, u radu su obrađeni akti i propisi objavljeni u službenim glasilima, službeni shematizmi te s temom povezana znanstvena i stručna literatura. O Balkanskoj banci do sada su provedena samo rijetka rubna istraživanja, uglavnom u sklopu istraživanja o politici i gospodarstvu te političarima i gospodarstvenicima. Tako je 2001. godine objavljen članak Mire Kolar-Dimitrijević Buran život dr. Dušana Plavšića (1875-1965), kojemu glavna tema nije bila Balkanska banka, ali je ipak ukratko obrađena u kontekstu Plavšićeva života i rada. Treba napomenuti da se u Arhivu Jugoslavije u Beogradu, u fondu AJ-65. Ministarstvo trgovine i industrije Kraljevine Jugoslavije (1918-1941) nalazi dosje Balkanske banke sa sačuvanim dokumentima iz 1925., 1926. i 1928. godine (fascikl 1465, jedinica opisa 2449), koji nisu obrađeni u ovom članku. ${ }^{1}$ Ti dokumenti nalaze se u fondu Ministarstva trgovine i industrije zato što je navedeno Ministarstvo bilo nadležno za nadzor nad poslovanjem novčarskih zavoda u Kraljevini Jugoslaviji, te je prikupljalo podatke o njima. ${ }^{2} S$ obzirom na to da je na svakoj redovnoj ili izvanrednoj godišnjoj glavnoj skupštini novčarskih zavoda, pa i onoj Balkanske banke, bio prisutan i izaslanik ministra trgovine $\mathrm{i}$ industrije, jedan primjerak skupštinskoga zapisnika obvezno je dobivalo i Ministarstvo trgovine i industrije. Kako su u fondu obitelji Plavšić pohranjenom u Hrvatskom državnom arhivu sačuvani primjerci zapisnika sa sjednica tijela uprave Balkanske banke te druga relevantna poslovna dokumentacija, nije bilo potrebe za daljnjim istraživanjima u Arhivu Jugoslavije. ${ }^{3}$

\footnotetext{
1 Ksenija Mirosavljević, "AJ-65. Ministarstvo trgovine i industrije Kraljevine Jugoslavije (1918-1941)," (sumarno-analitički inventar, Arhiv Jugoslavije, Beograd, s. a.), str. 2808.

2 Navedeno Ministarstvo imalo je sedam odjeljenja, od kojih je 6. bilo Odjeljenje za kreditne ustanove i osiguranje. Njegova nadležnost bila je da u granicama i prema propisima Zakona o akcionarskim društvima i drugim specijalnim zakonima obavlja nadzor nad svim povlaštenim i nepovlaštenim ustanovama, organiziranim u obliku dioničkih društava ili zadruga za uzajamno pomaganje, a koje su imale za cilj zasnivanje i podizanje trgovačkoga, zanatskoga, industrijskoga i hipotekarnoga kredita, u vezi s primanjem uloga na štednju, te obavljanjem drugih bankarskih poslova i dr. Usp. Siniša Lajnert, "Arhivistički prikaz sustava bankovno-novčarskih institucija u Hrvatskoj do likvidacije privatnih kreditnih poduzeća (1846-1949)," (doktorski rad, Sveučilište u Zagrebu, 2008), str. 193.

3 U fondu obitelji Plavšić sačuvani su sljedeći zapisnici glavnih skupština, upravnoga odbora, vjerovničkoga odbora, nagodbenoga odbora, likvidacijskoga odbora te garancijskoga sindikata: izvanredna glavna skupština dioničara banke od 18. travnja 1925.; zapisnici upravnoga odbora za 1923.; zapisnik
} 
Za razvoj jugoslavenskoga bankarstva od osobitoga je značenja razdoblje od 1920. do 1924. godine. Stvaranje Kraljevine Srba, Hrvata i Slovenaca (SHS), potreba i želja za ekonomskom samostalnošću uopće, a posebice na području bankarstva, te odmicanje od bečkoga i budimpeštanskoga tutorstva, dovelo je do "nacionalizacije" banaka u kojima je bio prisutan bečko-peštanski kapital. U trenutku raspada Austro-Ugarske Monarhije na našem prostoru postojao je određen broj banaka koje su do kraja Prvoga svjetskoga rata bile uglavnom ekspoziture bečkih i budimpeštanskih banaka. Primjerice, to su bile podružnice bečke i budimpeštanske Austro-ugarske banke, bečkoga Wiener Bank-Verein, budimpeštanske Ugarske banke i dioničarskoga trgovačkoga društva te Peštanske ugarske komercijalne banke. Stvaranjem Kraljevine SHS, na temelju odgovarajućih zakonskih propisa, provedeno je preuzimanje banaka $s$ austrijskim i mađarskim kapitalom. Već 30. travnja 1919. ministar trgovine i industrije Kraljevstva Srba, Hrvata i Slovenaca donio je Rješenje o popisu, sekvestru i likvidaciji imovine neprijateljskih podanika. Uredbom o imovini neprijateljskih podanika od 21. lipnja 1920. i Zakonom o prelazu celokupne imovine bivše Austro-Ugarske Monarhije u svojinu naše države od 15. travnja 1922. taj je je proces okončan. Sva pokretna i nepokretna imovina u vlasništvu bivše Austro-Ugarske Monarhije smatrana je opće-državnom, te je njome raspolagala Vlada Kraljevine SHS. ${ }^{4}$ Bečki i budimpeštanski kapital djelomično je zamijenjen čehoslovačkim, švicarskim, francuskim, belgijskim, engleskim, a donekle i talijanskim kapitalom. Privilegovana narodna banka Kraljevine Srbije preimenovana je u Narodnu banku Kraljevine Srba, Hrvata i Slovenaca te je njezin djelokrug proširen na cijelo Kraljevinu. Narodna banka otvorila je podružnice u mjestima u kojima su prethodno postojale podružnice Austro-ugarske banke (Banja Luka, Ljubljana, Maribor, Mostar, Veliki Bečkerek, Novi Sad, Osijek, Pančevo, Sarajevo, Split, Subotica, Varaždin, Vršac, Zagreb, Zemun). ${ }^{5}$ Budući da su uslijed inflacije ${ }^{6}$ do 1924 . postojale

konferencije članova ravnateljstva i nadzornoga odbora od 5. prosinca 1923.; zapisnici vjerovničkoga odbora za 1923.; zapisnici nagodbenoga odbora za 1923.; izvješća i zapisnici likvidacijskoga odbora banke za 1925., 1926., 1928., 1929., 1930., 1937., 1938., 1939., 1940.; zapisnik sjednice garancijskoga konzorcija Balkanske banke od 27. ožujka 1925.; zapisnik sjednice garancijskoga sindikata od 3. travnja 1925. Usp. HR-HDA-757. Plavšić, dosje: zapisnici Balkanske banke d.d. - garancije; zapisnici sjednica tvrtke "ing. Nikola Plavšić" iz Zagreba (kut. 5); dosje: spisi o likvidaciji Balkanske banke d.d. (1922-1948) (kut. 59).

4 Lajnert, "Arhivistički prikaz," str. 192-194, 210-211, 674, 706-707, 710-711; Narodna banka 1884.-1934. (Beograd: Zavod za izradu novčanica Topčider, 1934), str. 114-115; Rješenje o popisu, sekvestru i likvidaciji imovine neprijateljskih podanika, NN 106/1919; Zakon o Narodnoj banci Kraljevstva Srba, Hrvata i Slovenaca, SN 22/1920.

5 Zakon o Narodnoj banci Kraljevstva Srba, Hrvata i Slovenaca, SN 22/1920. Službeno preuzimanje i otvaranje pojedinih bivših podružnica Austro-ugarske banke na hrvatskim prostorima od strane Narodne banke bilo je izvršeno 1920. i 1921.: podružnica u Varaždinu 19. srpnja 1920., podružnica u Osijeku 23. srpnja 1920., podružnica u Zagrebu 24. srpnja 1920., podružnica u Splitu 1. siječnja 1921. Usp. Narodna banka 1884.-1934., str. 114-115.

6 Prema definiciji, inflacija je prekomjerno izdavanje papirnoga novca za financiranje državnih rashoda u razdoblju teških političkih i financijskih teškoća i, u vezi s time, brzo opadanje njegove vrijed- 
mogućnosti velikih zarada, došlo je do velikoga rasta postojećih banaka te osnivanja novih, manjih i većih. ${ }^{7}$ Tako je godine 1920. dionički kapital banaka na prostoru Kraljevine SHS iznosio 461,3 milijuna dinara, godine 1921. iznosio je 829,8 milijuna dinara, godine 1922. iznosio je 1.389,3 milijuna dinara, godine 1923. iznosio je 1.783,7 milijuna dinara, a godine 1924. iznosio je čak $1.959,2$ milijuna dinara. Rapidni proces proširenja banaka zaustavljen je tijekom 1924. godine. Obilje novca u periodu 1920.-1924., zbog inflacije i iseljeničkih doznaka, nije plasirano na domaće burze, nego je ili izravno investirano ili ulagano u banke. Štedni ulozi naglo su rasli. Potražnja za novčanim kapitalom u razdoblju inflacije bila je izuzetno velika. Banke su često nastojale iskoristiti tu konjukturu ${ }^{8}$ visokih dobitaka osnivanjem, financiranjem i vođenjem novih trgovačkih i industrijskih poduzeća, pri čemu su ti ulozi zadržavali formu kratkoročnih kredita, no u stvari bili su čisti investicijski, dakle srednjoročni ili uglavnom dugoročni. Stavke dužnika banaka u Kraljevini narasle su od 906,8 milijuna dinara u 1920. godini na $3.367,9$ milijuna u 1921. godini, a 1924. godine iznosili su $6.901,3$ milijuna

nosti. U prvim godinama nakon završetka Prvoga svjetskoga rata najveći dio državnih rashoda nije mogao biti financiran samo porezima, pa je financiran ili tiskanjem novčanica kao pravoga papirnoga novca ili emisijom velikih državnih zajmova. Inflacija je bila opća pojava, ali je u državama koje su izgubile rat bila znatno veća. U Kraljevini SHS inflacija je bila najjača u razdoblju od 1919. do 1921. i trajala je do pred kraj 1923. godine. Glavni razlog bio je nerazmjer između državnih rashoda i redovnih državnih prihoda. Država je također pokušala olakšati svoju financijsku situaciju povećanjem poreza i zajmovima. Usp. Jozo Tomašević, Novac i kredit (Zagreb: vlastito izdanje), str. 161, 352-356, 375.

7 Tijekom 1919. osnovano je više banaka s različitim vrijednostima dioničkih glavnica: Sveopća zanatlijska banka d.d. Zagreb (4,000.000 dinara), Brodsko trgovačko i mjenjačno d.d. u Brodu na Savi (1,500.000 dinara), Hrvatska gospodarska banka d.d. Zagreb (750.000 dinara), Pomorska banka Gruž (2,000.000 dinara). Godine 1920. vrijednosti glavnica novoosnovanih banaka bile su sljedeće: Banka J. Kreutzer d.d. Zagreb (3,000.000 dinara), Bankovno i mjenjačno d.d. Zagreb (1,000.000 dinara), Braća Turković bankarska radnja d.d. Zagreb (10,000.000 dinara), Diskontna banka d.d. Zagreb (1,000.000 dinara), Hrvatska banka i štedionica d.d. Bakar (650.000 dinara), Jugoslavenska industrijska banka d.d. Split (3,750.000 dinara), Međunarodna banka d.d. Zagreb (5,000.000 dinara), Središnja privredna i zadružna banka d.d. Zagreb (10,000.000 dinara), Trgovačka banka d.d. Nova Gradiška (1,000.000 dinara), Srpska centralna banka d.d. Osijek (3,000.000 dinara), Zadružna banka d.d. Split (2,500.000 dinara). Godine 1921.: Československa banka d.d. Daruvar (1,000.000 dinara), Domovinska banka d.d. Osijek (1,250.000 dinara). Godine 1922.: Banka R. Sever d.d. Zagreb (3,000.000 dinara), Bračko-amerikanska banka d.d. Supetar na Braču (2,000.000 dinara), Dobrovoljačka banka d.d. Zagreb (5,000.000 dinara), Srpska kreditna banka d.d. Otočac (400.000 dinara), Srpska privredna banka d.d. Zagreb (2,500.000 dinara), Šibenska okružna banka d.d. Šibenik (500.000 dinara). Godine 1923.: Banka Jugoslavija d.d. u Bakru (500.000 dinara), Dubrovačka vjeresijska banka Dubrovnik (1,000.000 dinara), Gostioničarska zadružna banka d.d. Zagreb (3,000.000 dinara), Hrvatska seljačka zadružna banka d.d. Zagreb (7,682.345 dinara). Usp. Rudolf Hanel, Compass: Finanzielles Jahrbuch 1925: Band III: Jugoslavien, Ungarn (Zagreb: Kompas, 1925), str. 161-162, 168, 186-187, 197, 203, 205, 212, 241, 249-251, 276, 282-284, 291, 312-317. Opširnije o osnivanju, fuzioniranju i likvidaciji pojedinačnih banaka i štedionica u razdoblju Kraljevine SHS, odnosno Jugoslavije usp. Lajnert, "Arhivistički prikaz," str. 588-815.

8 Konjuktura (lat.), 1. dobra prilika (za zaradu); 2. sve značajke koje karakteriziraju stanje kapitalističke privrede: kretanje cijena, tečaja vrijednosnih papira, zarade, dividenada, uopće stanje na tržištu s obzirom na odnos ponude i potražnje (dobra i loša konjuktura). Usp. Bratoljub Klaić, Rječnik stranih riječi: Tuđice i posuđenice (Zagreb: Nakladni zavod Matice hrvatske, 2001), s. v. konjuktúra. 
dinara. Iste godine vlastita sredstva i štedni ulozi banaka iznosili su zajedno 7.103 milijuna dinara. Dajući velike investicijske kredite, banke u Kraljevini povrijedile su dva osnovna pravila bankarske politike: pravilo likvidnosti i donekle pravilo sigurnosti. Naime, banke su svojim ulozima financirale dugoročne plasmane, koji su, samim time što su bili dugoročni, bili dosta nesigurni. No, na tadašnjem tržištu nije postojala mogućnost kratkoročnoga plasmana (tromjesečna apsolutno likvidna trgovačka mjenica), burze su angažirale banke samo minimalno, a blagajničkih zapisa tada uopće nije bilo. Na uloge kao jedini izvor kapitala su se, međutim, plaćale velike kamate, koje su se morale otplaćivati. U protivnom, izgubio bi se teren u konkurenciji drugih banaka. Kamatu je, dakle, trebalo zaraditi. Tako su banke zapravo silom prilika ušle u te investicijske poslove. Sve je bilo u redu dok je trajala inflacija i veliki iznosi novih uloga stalno pritjecali te dok su financijski plasmani banaka donosili velike dobitke. No 1924. godine nastupio je preokret, ušlo se je u razdoblje deflacije, ${ }^{9}$ pa je tako zaustavljen rapidni proces proširenja banaka. Mnoge banke pokazale su se uslijed različitih razloga nesposobne za poslovanje. Žrtve su za banke bile velike, ali i za vjerovnike mnogih propalih banaka, tj. za ulagače. Velika je količina kapitala, dakle, bila upućena pogrešnim putem. ${ }^{10}$

Balkanska banka već se je nakon osnutka brojila među bitnije domaće zavode. Tomu je najzaslužniji bio njezin predsjednik, bivši direktor Jugoslavenske banke i predsjednik Zagrebačke burze za robu i vrednote, Dušan Plavšić. ${ }^{11}$ Balkanska banka dobila je još više na cijeni kada je Plavšić došao u Ministarstvo financija kao pomoćnik ministra Koste Kumanudija ${ }^{12}$ te obavljao sve dolarske

\footnotetext{
9 Deflacija (lat.), smanjivanje količine papirnoga novca u opticaju pomoću različitih ekonomskih mjera radi povišenja njegove kupovne vrijednosti, smanjenja cijena i dr. Usp. Klaić, Rječnik stranih riječi, s. v. deflácija.

10 Usp. Tomašević, Novac i kredit, str. 229-232; Siniša Lajnert, "Diskontna banka d.d. Zagreb (1920.1948.)," Arhivski vjesnik 61 (2018): str. 158-159.

11 Dušan Plavšić rođen je 24. travnja 1875. u Vinkovcima, a preminuo je 18. prosinca 1965. u Zagrebu. Njegov otac Nikola Atanasije Plavšić bio je dugogodišnji tajnik Trgovačko-obrtničke komore u Osijeku. Između ostaloga, Dušan Plavšić bio je tajnik Prve hrvatske štedionice u Zagrebu, ravnatelj zagrebačke podružnice Hrvatske zemaljske banke d.d. Osijek, predsjednik Zagrebačke burze za robu i vrednote, ravnatelj Balkanske banke d.d. Zagreb, pomoćnik ministra financija Koste Kumanudija. Opširnije o Dušanu Plavšiću usp. Mira Kolar, "Buran život dr. Dušana Plavšića (1875.-1965.)," Osječki zbornik 24-25 (2001): str. 131-143.

12 Zahvaljujući realnoj analizi poslovanja Slavenske banke, koju je Plavšić polovicom 1922. poslao ministru financija Kosti Kumanudiju, on ga je u kolovozu 1922. pozvao u Ministarstvo kao svojega pomoćnika. Njegov je zadatak bio pomoći u spašavanju državnih financija. Sredstva koja su dobivena u sukcesiji Austro-ugarske banke i dio Blairova zajma (10,000.000 dinara) uložena su u Francuskoj za podizanje novoga zajma. Dinar je bio uspješno osnažen. Usp. Kolar, "Buran život dr. Dušana Plavšića," str. 135; Mira Kolar-Dimitrijević, "O osnutku i radu Zagrebačke burze do 1945. godine," Radovi 28 (1995): str. 204.
} 
transakcije iz Blairova zajma ${ }^{13}$ za jačanje vrijednosti dinara. ${ }^{14}$ Kada je vrijednost dinara počela rasti, Plavšić je zadobio simpatije svekolike javnosti. Međutim, sve je to bilo kratkotrajno i prividno. Dinar se je za kratko vrijeme vratio na svoju staru vrijednost. Propala je koalicijska vlada, a iz Ministarstva financija morao je uz Kumanudija otići i Plavšić. ${ }^{15}$ Tada je počela i propast Balkanske banke. Balkanska banka u stvari je propala onoga trena kada je Dušan Plavšić propao kao pomoćnik ministra financija Koste Kumanudija. Vlada je pala već 16. prosinca 1922. te je zamijenjena radikalnom vladom Nikole Pašića. Za ministra financija došao je radikal Milan Stojadinović. Dušan Plavšić počeo je kritizirati njegovu financijsku politiku, a napose njegov uravnoteženi budžet, koji je bitno pogađao zapadni dio Kraljevine SHS. Na taj način pao je u njegovu i kraljevu nemilost. Bio je jedini pomoćnik ministra bez dodijeljene bilo kakve državne mirovine, a njegovi prijedlozi Vladi bili su sve do smrti kralja Aleksandra odbačeni. ${ }^{16}$

13 Godine 1922. zaključen je kod banke Blair\&Co. u New Yorku zajam u iznosu od 100,000.000 dolara, ali je uspješno plasirano samo 15,5 milijuna dolara u 8-postotnim obveznicama. Drugi dio od 30 milijuna dolara emitiran je tek 1927. godine. Iako su ti zajmovi prvenstveno bili namijenjeni obnovi željezničkoga prometa i ostalih prometnih sredstava, njihov je najveći dio uporabljen za pokriće redovnih državnih administrativnih rashoda. Usp. Tomašević, Novac i kredit, str. 161.

${ }_{14}$ Velika inflacijska ponuda novca koja je bila pojačana širokogrudnom kreditnom i investicijskom politikom privatnih banaka u Kraljevini SHS, a s druge strane opća glad za robom stvorili su u prvih 4-5 godina nakon rata izuzetno povoljnu konjukturu. No, to je bila opća pojava u svim zemljama. U razdoblju 1920.-1926. najnižu prosječnu mjesečnu vrijednost na burzi u Zürichu imao je dinar u travnju 1923., a nakon toga vrijednost mu je samo rasla. Od presudnoga utjecaja na razvoj tečaja dinara u Zürichu bila je opća financijska i politička konstelacija Kraljevine SHS i velika pasivnost bilance plaćanja. Intervencije učinjene u korist dinara na burzi u Zürichu, koje su pokazivale trenutačne uspjehe, ostale su do kraja 1923. bez stvarnoga trajnoga uspjeha. Odgovornim osobama nekih europskih zemalja, koje su $\mathrm{u}$ ratu i neposredno nakon njega zapale u inflaciju srednjih razmjera, postalo je jasno da se valuta ne može revalorizirati na predratni zlatni paritet, pa su ju nastojali barem malo ojačati, "osnažiti" u intervalutarnoj vrijednosti, da bi se na toj vrijednosti stabilizirala. Ideja "snaženja", odnosno jačanja valute bila je općenito prihvaćena kod država pobjednica Prvoga svjetskoga rata, pa nije bilo nimalo čudno da je tu politiku prihvatila i Kraljevina SHS. Od početka politike "snaženja" dinara, sve do faktične stabilizacije u kolovozu 1925., možemo reći da je vrijednost dinara u Zürichu bila plod sustavnih intervencija od strane vlade. No to je vodilo jugoslavensku privredu u oštru deflacijsku krizu, koja je progutala veliki dio novoosnovanih industrija i banaka, a bankama i poduzećima nanijela velike gubitke. U tom razdoblju nalazi se začetak problema dugova koji je kasnije pogodio Kraljevinu. Rijetki pojedinci bili su svjesni opasnosti te politike. U razdoblju deflacije i "snaženja" dinara 1923.-1925. interesi narodne privrede bili su po prvi puta podređeni nezdravoj valutnoj politici. Drugi puta to je učinjeno 1931. i 1932., ali s težim posljedicama. U kolovozu 1925. tečaj dinara u Zürichu fiksiran je na 9,135 švicarskih franaka za 100 dinara te je, sustavnom intervencijom od strane mjerodavnih osoba i ustanova održan sve do zakonske stabilizacije dinara sredinom 1931. godine. Usp. Tomašević, Novac i kredit, str. 161-165.

15 Slučaj Balkanske banke, Narodna straža 3, br. 28 (28. srpnja 1923): str. 2. Prema pisanju Narodne straže Dušan Plavšić kao pomoćnik ministra financija Koste Kumanudija preko Balkanske banke obavljao je dolarske transakcije iz Blairova zajma za poboljšanje dinara. Kada je propala koalicijska vlada i Plavšić otišao iz Ministarstva financija, dolarskih transakcija više nije bilo pa je Balkanska banka trebala ograničiti svoje poslovanje. Umjesto toga započela je trgovinu čekovima bez pokrića, na goleme svote dolara i engleskih funti. Takvim poslovanjem Balkanska banka zapala je u neprilike. Suma njezine pasive računala se preko 100,000.000 dinara, te je morala putem suda zamoliti nagodbeni postupak.

16 Kolar, "Buran život dr. Dušana Plavšića," str. 134-135. Akt o razrješenju nije nikada primio. U zbirci Plavšićevih dokumenata sačuvana je molba upućena 1940. Ministarstvu financija u Beogradu, u kojoj 


\section{Balkanska banka d.d. Zagreb}

Dušan Plavšić, predsjednik Zagrebačke burze za robu i vrednote i bivši član uprave i egzekutive Jugoslavenske banke d.d. ${ }^{17}$ iz Zagreba, Rokova ulica br. 9, Matija Herceg, bivši glavni ravnatelj Jadranske banke Trst ${ }^{18}$ iz Zagreba, Tuškanac br. 18, i Stanislav I. Lubienski, bivši glavni ravnatelj i član uprave Slavenske banke d.d. ${ }^{19}$ Zagreb iz Zagreba, Veliki dol br. 29, objavili su 10. siječnja 1922. tzv. utemeljiteljnu osnovu te su podjedno sazvali konstituirajuću glavnu skupštinu Balkanske banke d.d. Zagreb, koja je održana 25. veljače 1922. u Plavšićevu stanu u 15 sati. ${ }^{20}$ Kr. sudbeni stol kao trgovački sud u Zagrebu donio je 4. ožujka 1922. odluku temeljem koje je potvrđen primitak zapisnika konstituirajuće skupštine Balkanske banke od 25. veljače 1922. te je zajedno s prilozima pohranjen u zbirku isprava. Nakon što su pravila usklađena s čl. 157 Trgovačkoga zakona, ${ }^{21}$ određen je u trgovačkom registru za društvene tvrtke upis Balkanske

podsjeća da je bio pomoćnik ministra financija u vladi Nikole Pašića. $S$ obzirom na to da mu je taj dokument bio potreban, zamolio je Ministarstvo da mu naknadno izda akt o razrješenju. Usp. HRHDA-757. Plavšić, dosje: razne molbe na ministarstva (kut. 42).

17 Jugoslavenska banka d.d. Zagreb potječe od Hrvatske zemaljske banke d.d. Osijek osnovane 1909. po Živnostenskoj banci u Pragu, preuzećem bankovne tvrtke Sorger, Weiszmayer \&Cie, banke i mjenjačnice u Osijeku, a pod upravom i ravnanjem Oskara Weiszmayera i Julija Sorgera. U trgovački registar u Osijeku upisana je 1920. promjena naziva u: Jugoslavenska banka d.d. prije Hrvatska zemaljska banka d.d. ili skraćeno: Jugoslavenska banka d.d. Imala je podružnice u Zagrebu, Beogradu, Brodu na Savi (Slavonski Brod), Crikvenici, Karlovcu, Ljubljani, Novom, Osijeku, Subotici, Sušaku, Varaždinu i Vukovaru. Od 1941. poslovala je pod nazivom Hrvatska zemaljska banka. Likvidacija je započeta 1941., a završila 1949. Usp. Lajnert, “Arhivistički prikaz," str. 649-651, 655-656.

18 Jadranska banka Trst (Banca Adriatica in Trieste, Adriatische Bank) osnovana je 1905., a 1920. u trgovački registar u Zagrebu upisana je Jadranska banka u Zagrebu, kao podružnica centrale u Trstu. Temeljem rješenja ministra trgovine i industrije 1921. osnovana je Jadranska banka Beograd. Preuzela je jugoslavenske podružnice Jadranske banke Trst u Bledu, Cavtatu, Celju, Dubrovniku, Herceg Novom, Jelsi, Jesenicama, Korčuli, Kotoru, Kranju, Ljubljani, Mariboru, Metkoviću, Osijeku, Prevaljama, Sarajevu, Šibeniku, Splitu, Tržiču i Zagrebu. U trgovački registar u Zagrebu 1922. upisana je podružnica Jadranske banke u Zagrebu (s društvenim pravilima iz 1921.). Jadranska banka Beograd preimenovana je 1924. u Jadransko-podunavska banka Beograd. Podružnica u Zagrebu 1925. prestala je s poslovanjem. Svu aktivu i pasivu preuzela je centrala u Beogradu. Usp. Lajnert, "Arhivistički prikaz," str. 653-654.

19 Slavenska banka potječe od Kotarske štedionice d.d. u Samoboru osnovane 1911. godine. Na izvanrednoj glavnoj skupštini štedionice održanoj 1915. zaključeno je da se njezino sjedište premjesti u Zagreb. Naziv je promijenjen 1918. u Narodna banka d.d. Zagreb, te potom 1921. u Slavenska banka d.d. u Zagrebu. U trgovačkom registru u Zagrebu 1930. upisana je likvidacija banke. Okružni narodni sud za grad Zagreb u trgovačkom registru upisao je 1946. kod Slavenske banke d.d. u likvidaciji u Zagrebu ponovo likvidaciju, temeljem rješenja Ministarstva financija FNRJ. Iz trgovačkoga registra brisana je 1947. Usp. Lajnert, "Arhivistički prikaz," str. 669, 684-686, 746; Siniša Lajnert, "HRHDA-541. Slavenska banka d.d. Zagreb (1911-1947)," (sumarni inventar fonda, Hrvatski državni arhiv, Zagreb, 2011), str. 3-5.

20 HR-HDA-757. Plavšić, Utemeljiteljna osnova i arak za supskripciju tvrtke: Balkanska banka d.d. od 10. siječnja 1922. (kut. 42).

${ }^{21}$ Temeljem čl. 157 tada još uvijek važećega Trgovačkoga zakona od 16. svibnja 1875., u pravilima društva trebalo je navesti naziv i sjedište tvrtke, predmet poduzeća i njegovo trajanje, iznos temeljne 
banke dioničarskoga društva u Zagrebu. Banka se je bavila štedioničkim, bankovnim, burzovnim, financijskim, industrijskim i transportnim poslovima. Dionička glavnica banke iznosila je 50,000.000 dinara ${ }^{22}(200,000.000$ kruna) razdijeljena u 500.000 dionica po 100 dinara (400 kruna) koje su glasile na donosioca, od čega je do tada bilo izdano i potpuno uplaćeno 12,500.000 dinara $(50,000.000$ kruna), u 125.000 dionica. Ustroj društva činili su: glavna skupština dioničara, upravni odbor (ravnateljstvo) i nadzorno vijeće. ${ }^{23}$ Glavnu skupštinu činili su na istoj prisutni dioničari. Posjed pet dionica davao je pravo na jedan glas. Glavna skupština bila je redovita ili izvanredna. Glavna skupština mogla je donositi zaključke ako je bilo prisutno barem 7 dioničara koji su zastupali najmanje dvadeseti dio uplaćene dioničke glavnice. Upravni odbor bio je vrhovno vodstvo zavoda, a sastojao se je od 9-18 članova koje je glavna skupština birala na tri godine. Temeljem čl. 183 Trgovačkoga zakona, ${ }^{24}$ prvi upravni odbor imenovali su utemeljitelji banke. Upravni odbor birao je između svojih članova predsjednika i podpredsjednika, a njihova je služba trajala cijelo vrijeme trajanja njihova mandata u upravnom odboru. Nadzorno vijeće sastojalo se je od 3 do 9 ćlanova, koje je birala glavna skupština, prvi puta na jednu godinu, a zatim na tri godine. Nadzorno vijeće nadziralo je poslovanje društva u svim njegovim djelatnostima. Bilo je dužno pregledati društvene knjige i blagajnu najmanje četiri puta godišnje, te ispitati godišnje iskaze predložene upravnomu odboru i o tom izvijestiti glavnu skupštinu. Kao članovi ravnateljstva banke upisani su: 1 . Dušan Plavšić, ravnatelj banke u Zagrebu; 2. Matija Herceg, ravnatelj banke u Zagrebu; 3. grof Stanislav Lubienski, ravnatelj banke u Zagrebu; 4. Valerijan Riesner, inženjer u Zagrebu; 5. barun Josip Rajačić, veleposjednik u Vukovaru; 6. barun Amon Rukavina, veleposjednik u Zagrebu; 7. Radak Radaković, pukovnik u mirovini u Zagrebu;

glavnice, podatke o dionicama i drugim vrijednosnicama, podatke o glavnoj skupštini, ravnateljstvu i nadzornom odboru, podatke o bilanci, podijeli dobitka, potpisivanju tvrtke i sl. Usp. Trgovački zakon, SZN 44/1877.

22 Zakonom od 31. prosinca 1921. za novčanice Austro-ugarske banke koje su primljene kao nacionalni novac, $s$ time što su žigosane pa zatim markirane i potom zamijenjene za krunsko-dinarske novčanice u odnosu 4 markirane krune za 1 dinar, utvrđen je kao stalan i konačan odnos: 4 krune za 1 dinar, po kojem je zamjena i provedena. Usp. Zakon o konačnom odnosu krunske novčanice prema dinarskoj, SN 238/1922. Kao primjer usporedbe vrijednosti dinara u odnosu na druge valute navodim tečajeve iz travnja 1924. godine: 100 francuskih franaka $=420$ dinara, 100 talijanskih lira $=344$ dinara, 100 švicarskih franaka $=1.390$ dinara, 100 danskih kruna $=1.255$ dinara, 100 švedskih kruna $=2.170$ dinara, 100 rubalja $=10$ dinara, 1 engleska funta $=345$ dinara, 1 američki dolar $=80$ dinara. Usp. Naređenje delegata ministra financija od 8. travnja 1924., NN 86/1924. Da bismo shvatili kupovnu vrijednost dinara u Kraljevini Jugoslaviji te ju usporedili sa stvarnom vrijednošću kapitala banke, mogu poslužiti sajamske cijene blaga u Zagrebačkoj županiji od 30. siječnja do 12. veljače 1924. po kilogramu žive vage: volovi 8-16 dinara, bikovi 7-15 dinara, krave 7-13 dinara, junice 7-14 dinara, telad 18-22 dinara, svinje 20-26 dinara. Usp. Tržne cijene blagu na sajmovima, NN 39/1924.

23 Ustroj i nadležnost tijela uprave dioničarskih društava (glavna skupština, tj. skup svih dioničara, ravnateljstvo i nadzorni odbor) regulirani su čl. 176-200 Trgovačkoga zakona od 16. svibnja 1875. Usp. Trgovački zakon, SZN 44/1877.

24 Trgovački zakon, SZN 44/1877. 
8. Slavko Dukanac, ${ }^{25}$ odvjetnik u Beogradu; 9. Jovan Šumanović, veleposjednik u Šidu. Ostali članovi ravnateljstva trebali su biti upisani kada se podnesu njihovi potpisi. ${ }^{26}$ Banka je imala sjedište u Zagrebu na Jelačićevu trgu br. $25 .{ }^{27}$

Prema prvotnom popisu upisanih i uplaćenih dionica Balkanske banke (125.000 dionica u iznosu od 12,500.000 dinara) najveći dioničari banke bili su Dušan Plavšić, Matija Herceg i Stanislav Lubienski (Zagreb) kao grupa s 50.000 dionica (5,000.000 dinara), Pavlinović i dr. Sylagyi (Beograd) s 25.000 dionica (2,500.000 dinara), Jovan Šumanović (Šid) s 6.000 dionica (600.000 dinara) + 4.000 dionica (400.000 dinara), barun Josip Rajačić (Vukovar) s 5.000 dionica (500.000 dinara), Fran Petrić (Zagreb) s 5.000 dionica (500.000 dinara), Dušan Plavšić (Zagreb) s 2.500 dionica (250.000 dinara), barun Amon Rukavina (Zagreb) s 2.500 dionica (250.000 dinara), Lavoslav Schwarz (Zagreb) s 2.500 dionica (250.000 dinara), Matija Herceg (Zagreb) s 2.500 dionica (250.000 dinara), grof Stanislav I. Lubienski (Zagreb) s 2.500 dionica (250.000 dinara), ali postojalo je i mnoštvo drugih. ${ }^{28}$

Temeljem važećega Zakonskoga članka XVII. (Obrtni zakon) od 18. svibnja 1884. godine, pravne osobe mogle su se baviti bankovnim obrtom uz uvjet da postave poslovođu, te uz odgovarajuću prijavu prvostupanjskoj vlasti. Za obavljanje svojega poslovanja pravne osobe dobivale su obrtnu dozvolu (iskaz-

\footnotetext{
${ }^{25}$ U nekim izvorima spominje se i kao Savko Dukanac. Usp. Rudolf Hanel, Compass: Finanzielles Jahrbuch 1923: Band III: Jugoslavien, Ungarn (Zagreb: Compassverlag, 1923), str. 252; Hanel, Compass: Finanzielles Jahrbuch 1925, str. 312.

26 HR-HDA-152. SFD, dosje Balkanska banka d.d. Zagreb, Odluka Kr. sudbenog stola kao trgovačkog suda u Zagrebu od 4. ožujka 1922. (kut. 302); HR-HDA-757. Plavšić, dosje o likvidaciji Balkanske banke d.d. (1922.-1948.), Pravila Balkanske banke d.d. u Zagrebu od 25. veljače 1922. (kut. 59). Usp. HR-DAZG-1249. BB/Z, Odluka Kr. sudbenog stola kao trgovačkog suda u Zagrebu od 4. ožujka 1922.

27 Hanel, Compass: Finanzielles Jahrbuch 1923: Band III, str. 252.

28 Potpun prvotni popis dioničara bio je sljedeći: Mihajlo Ebrić, Dragica Ebrić, Mor. Weinberger, Teodor Grünfeld, barun Josip Rajačić, Ignjat Fischer, T.G. Stipanović, Gustav Janeček, Pavlinović i dr. Sylagyi, Antonija Posledniković, Matija Lipovćak, Lavo Hoić, Braća Klein, Dušan Plavšić, Gustav Kraus, Leopold Mautner, Dragutin Heinzel, Josip Lončarić, Radak Radaković, D. Axelrad, grupa Plavšić, Herceg i Lubienski, Simo Zurunić, Jovan Šumanović, Josip Deutsch, barun Amon Rukavina, Fran Petrić, Ante Gašpić, Oscar Jellinek, Milan Milić, Mavro Sirmai, Vinko Zlatarić, Đuro Jančiković, Valerijan Riesner, Alfred Peyer, Hertman i Slavnić, Franjo Scholz, Trifun Kamenarović, dr. Roko Joković, Rudolf Kunz, Zvonimir T. Truta, Benko Kell, dr. Dragan Novosel, Braća Lauš, dr. Franjo Hanaman, Alexander Hanaman, Stjepan pl. Leitner, Josip Fulanović, Albert Hertman, Richard Najman, Milan Borić, Lavoslav Schwarz, Milan Rosenberg, Ladislav Holjevac, Ivan Ancel, Matija Herceg, Ćiril Iveković, Ferdo Šega, Jugoslavensko građevinsko poduzetništvo d.d. Zagreb, Antun Gueratto, Otokar Pacovsky, Branislav Tucich, Rudolf Armano, Ivan Sadil, Miroslav Rosenfeld, Marija Smolčić, Slavko Fugaš, dr. Rikard Plemić, August Scholz, Marija Tomay, Paula pl. Tomay, Ivan N. Ferić, Julius Kofler, Sava Đorđević, Anđela Gregorić, dr. Zdenko Longhino, Vilim Steiner, Artur Steiner, dr. Ljubomir Tomašić, dr. Ivan Juriša, Adolf Pick, Milivoj Stipčić, grof Stanislav I. Lubienski, Mavro Bischitz, Josip Löbl, Maksim Stern, Josip Marganj jun. i Ana Arlavi-Galina. Usp. HR-HDA-757. Plavšić, dosje Balkanska banka, Popis upisanih i uplaćenih dionica Balkanske banke d.d. (kut. 27).
} 
nicu), koja je pod određenim brojem bila upisana u obrtni registar (upisnik). ${ }^{29}$ U skladu s time Poglavarstvo slob. i kr. glavnoga grada Zagreba obavijestilo je 6. ožujka 1922. Kr. financijalno ravnateljstvo u Zagrebu da je Balkanska banka d.d. Zagreb (Jelačićev trg br. 25) prijavila da će se od 6. ožujka 1922. baviti bankovnim i mjenjačnim poslom, kao i svim u bankovnu struku pripadajućim poslovima, te da će namjestiti kao generalnoga ravnatelja Stanislava I. Lubienskoga. O tom je zagrebačko Poglavarstvo izdalo banci i obrtnu iskaznicu. ${ }^{30} \mathrm{Kr}$. sudbeni stol kao trgovački sud u Zagrebu upisao je 3. travnja 1922. u trgovačkom registru za društvene tvrtke člana upravnoga odbora Balkanske banke Vinka Zlatarića iz Zagreba. ${ }^{31}$ Kako su u međuvremenu ostali članovi ravnateljstva podnijeli svoje potpise, bili su i oni upisani u trgovački registar. Tada se je ravnateljstvo banke sastojalo od sljedećih članova: Dušan Plavšić, Matija Herceg, Stanislav Lubienski, Valerian Riesner, Josip Rajačić, Amon Rukavina, Radak Radaković, Slavko Dukanac, Jovan Sumanović, Bernhard Pavlinović i Vinko Zlatarić. Ravnatelj i prokurist bio je Milan Kastl, a ostali su prokuristi bili Ivo Arlavi, Anton Gueratto i Savko Fugaš. ${ }^{32}$ Nedugo nakon toga u ravnateljstvo je ušao i Franjo Ottenfels. ${ }^{33}$

Balkanska banka d.d. Zagreb otvorila je, po odobrenju ministra trgovine i industrije br. 1254 od 29. ožujka 1922. podružnicu u Beogradu s kapitalom od 5,000.000 dinara, koju je vodila pod imenom: Balkanska banka d.d. Zagreb filijala u Beogradu. ${ }^{34}$ Imala je i veće partnerske poslove, koje je financirala i kod kojih je participirala na dobitku: 1. izgradnja pruge Vardište-Šargan, koju je vodilo Građevno poduzeće "ing. Nikola Plavšić" iz Zagreba; 2. kupnja dobra Ludbreg u svrhu parcelacije; 3. suradnja s Dunavskom eksploatacijom šuma; 4. kupnja drvene građe Frana Petrića. ${ }^{35}$

Građevno poduzeće "ing. Nikola Plavšićc iz Zagreba ${ }^{36}$ sudjelovalo je od 1921. do 1923. u gradnji uskotračne pruge Vardište-Šargan koja je trebala pove-

\footnotetext{
29 Siniša Lajnert, "Jastrebarska dionička štedionica u Jastrebarskom: ustroj, djelovanje i likvidacija (1894-1948)," Arhivski vjesnik 58 (2015): str. 124.

30 HR-HDA-152. SFD, dosje Balkanska banka d.d. Zagreb, dopis Poglavarstva slob. i kr. glavnoga grada Zagreba upućen 6. ožujka 1922. Kr. financijskom ravnateljstvu u Zagrebu (kut. 302). Usp. HRDAZG-1249. BB/Z, Obrtna iskaznica za Balkansku banku d.d. Zagreb od 6. ožujka 1922.

31 Upisi tvrdka, NN 122/1922.

32 Hanel, Compass: Finanzielles Jahrbuch 1923: Band III, str. 252.

33 Hanel, Compass: Finanzielles Jahrbuch 1925, str. 312.

34 Trgovačke firme, SN 214/1922. Kr. sudbeni stol kao trgovački sud u Zagrebu upisao je 8. kolovoza 1922. u trgovačkom registru za društvene tvrtke podružnicu Balkanske banke d.d. u Beogradu. Usp. Upisi tvrtka, NN 215/1922. Sjedište joj je bilo na Obilićevu vencu br. 36. Hanel, Compass: Finanzielles Jahrbuch 1923: Band III, str. 252.

35 HR-HDA-757. Plavšić, dosje Balkanska banka, prikaz stanja Balkanske banke d.d. na 16. i 23. srpnja 1923., dodatak exposée (kut. 5 i 27).

${ }^{36}$ Inž. Nikola Plavšić, brat Dušana Plavšića, dobio je od države odobrenje za gradnju željeznice Vardište-Šargan.
} 
zati Bosnu sa Srbijom. ${ }^{37} \mathrm{Na}$ tom poslu, kao i vlasničkim udjelom u poduzeću, Balkanska banka participirala je s 30\%. Pored Balkanske banke udjele u tom poslu imali su Nikola Plavšić (30\%), Fran Petrić (30\%) i Dušan Plavšić (10\%). ${ }^{38}$ Dušan Plavšić bio je jedan od najvećih dioničara Balkanske banke, a ujedno je bio i dioničar Građevnoga poduzeća “ing. Nikola Plavšić”, te su on i brat Nikola zajedno ušli u posao koji je obećavao veliku zaradu. S obzirom na to da se je gradnja odvijala s poteškoćama i zastojima, zbog novčane krize u koje je poduzeće zapalo, ministar saobraćaja u srpnju 1923. donio je rješenje da se Plavšićevu poduzeću oduzme gradnja pruge. Drugi dio pruge radilo je poduzeće Fenix, a puštena je u promet 25. prosinca 1925. godine. Njome su iz Bosne u Srbiju prevožene sirovine (ugljen, drvo i sl.), a u suprotnom smjeru gotovi industrijski i poljoprivredni proizvodi. ${ }^{39}$ Poduzeće "ing. Nikola Plavšić” je za inventar, nabavu materijala, izgradnju pilane, stambenih zgrada, žične željeznice i dr. investiralo oko 27,000.000 dinara. Od toga iznosa otpadalo je na kredit, što ga je Balkanska banka dala, oko 14,700.000 dinara, a za razna žira, mjenice tvrtke i kupnju materijala te živežnih namirnica banka je bila u obvezi s oko 7,000.000 dinara. Partnerskim ugovorom ustanovljeno je za banku prvenstveno pravo ispred svih drugih vjerovnika za podmirenje njezine tražbine prema tvrtki, i to i iz naslova kredita, iz naslova garancija, i iz naslova uloga u glavnicu, te je banci u tu svrhu dano ugovorno založno pravo na svu društvenu imovinu. Ministarstvo saobraćaja u tumačenju građevnoga ugovora s tvrtkom, jednostrano i pravno neosnovano preuzelo je sav inventar i materijal tvrtke, stojeći na gledištu, da nastavlja gradnju s

37 Pruga je od strane Srbije projektirana još 1903. kao dio jadranske pruge Prahovo-Kotor (Dubrovnik). Gradnja je odlagana do 1906., kada je u Bosni puštena u promet pruga Sarajevo-Vardište s krakom Međeđa-Uvac (obje su završavale na granici sa Srbijom). Građena je u etapama, tako da je prvi vlak iz Stalaća u Užice stigao 1912. godine. Daljnja gradnja prema Bosni stala je zbog balkanskih i Prvoga svjetskoga rata. Poslije okupacije Srbije od strane austro-ugarske vojske 1915. i 1916. pristupljeno je definitivnoj izradi projekta, a nakon toga i samoj gradnji. Nakon rata radilo se malo tijekom razdoblja 1919.-1921., pa je Ministarstvo saobraćaja odlučilo da gradnju preda privatnim poduzećima. Poduzeće "ing. Nikola Plavšić" iz Zagreba preuzelo je taj posao u rujnu 1921. Usp. HR-HDA-757. Plavšić, dosje: željeznica Vardište-Šargan, izvješće direktora Direkcije za građenje novih željeznica u Beogradu iz 1923. upućeno ministru saobraćaja; izvješće poduzeća "ing. Nikola Plavšićc" nepoznatoga datuma; dopis Plavšićeva poduzeća Državnomu savjetu nepoznatoga datuma; komisijski izvještaj od 9. lipnja 1923.; izvješće Poduzeća Plavšić od 14. srpnja 1923. o uzrocima zbog kojih je stala gradnja pruge Vardište-Šargan; Nikola Turkalj, Gradnja željeznice Vardište-Užice, Tehnički list 6, br. 4 (15. veljače 1924): str. 45-50 (primjerak u fondu HR-HDA-757. Plavšić, kut. 3). Usp. Kolar, "Buran život dr. Dušana Plavšića," str. 134; Ilija Misailović i Radovan Glibetić, Šarganska osmica: Železnička pruga Užice-Vardište (Beograd: SANU, 2010), str. 491-493. Zahvaljujem Zoranu Bundalu na pojašnjenjima o toj željeznici.

38 Balkanska banka kupila je udio od baruna Amona Rukavine za iznos od 1,500.000 dinara.

39 Usp. HR-HDA-757. Plavšić, dosje: željeznica Vardište-Šargan, izvješće direktora Direkcije za građenje novih željeznica u Beogradu iz 1923. upućeno ministru saobraćaja; izvješće poduzeća "ing. Nikola Plavšić" nepoznatoga datuma; dopis Plavšićeva poduzeća Državnomu savjetu nepoznatoga datuma; komisijski izvještaj od 9. lipnja 1923.; izvješće Poduzeća Plavšić od 14. srpnja 1923. o uzrocima zbog kojih je stala gradnja pruge Vardište-Šargan; Nikola Turkalj, Gradnja željeznice Vardište-Užice, Tehnički list 6, br. 4 (15. veljače 1924): str. 45-50. Usp. Kolar, "Buran život dr. Dušana Plavšića," str. 134; Misailović i Glibetić, Šarganska osmica, str. 491-493. 
istim inventarom i materijalom, te na račun i štetu tvrtke. Uslijed toga tvrtka je bila primorana protiv Ministarstva saobraćaja pokrenuti parnični postupak, a banka poduzeti korake za osiguranje svoje tražbine. Kako je komisija koja je vodila gradnju spriječila provođenje založnoga prava, banka se je obratila sudu smatrajući da će svoju tražbinu od 14,700.000 dinara u cijelosti naplatiti. ${ }^{40}$

Banka je sudjelovala i u kupnji dobra Ludbreg radi parcelacije. Navedeno dobro kupio je član uprave Amon Rukavina, a banka je u tome participirala $s$ $50 \%$, uz uvjet da financira parcelaciju. ${ }^{41}$ Prema nekim podatcima, nakon propasti Austro-Ugarske Monarhije i stvaranjem Kraljevine Srba, Hrvata i Slovenaca, vlasnik ludbreškoga imanja grof Ladislav Batthyany prodao je svoj posjed zagorskomu barunu Amonu Rukavini, od koga ga je otkupila tvrtka Berger iz Zagreba za 7,200.000 dinara. ${ }^{42}$ Prema drugima, veleposjed je potpao pod državnu upravu jer dotadašnji vlasnici nisu bili državljani novostvorene Kraljevine SHS. Tvrtka Braća Berger, trgovina drvom d.d. Zagreb rasparcelirala je posjede kupljene od vlasnika, te zemlju (oko 6.000 jutara) po dosta visokim cijenama prodala seljacima. ${ }^{43}$ Provedba parcelacije zastala je kada je banka stupila u prinudnu nagodbu. Do tada je za kupnju isplaćen samo prvi obrok u iznosu od 1,000.000 dinara. Da je parcelacija provedena do kraja, banka je mogla dobiti iznos od čak 10,000.000 dinara. ${ }^{44}$

U poslu s Dunavskom eksploatacijom šuma Balkanska banka participirala je s 40\%. Riječ je o eksploataciji 2.500 hektara bukove šume kod Donjega Milanovca u Srbiji, na temelju ugovora grupe Radomira Kopše s državom. Šuma je davala $350.000 \mathrm{~m}^{3}$ drva, koje je prevoženo Dunavom u Beograd radi prodaje. ${ }^{45}$

\footnotetext{
${ }^{40}$ HR-HDA-757. Plavšić, dosje Balkanska banka u vezi s inž. Nikolom Plavšićem (gradnja željeznice Vardište-Šargan), dodatak izvješću (kut. 5).

41 Barun Amon Rukavina kupio je 1923. od kneza Batthyánya dobro Ludbreg u površini od oko 6.000 jutara, od kojih su oko 2.000 jutara bile šume, a ostatak oranice, livade i vinogradi. Ugovor je odobren od strane Ministarstva pravde rješenjem br. 5.463 od 4. lipnja 1923. Cijena je bila 8,835.000 dinara plativa u obrocima u roku od oko godinu dana. Kupnja je osigurana uložnicama Balkanske banke. HRHDA-757. Plavšić, dosje Balkanska banka u vezi s inž. Nikolom Plavšićem (gradnja željeznice VardišteŠargan), dodatak izvješću (kut. 5).

42 Usp. Marija Winter, "Ludbreški grad i njegovi gospodari," Podravski zbornik 6 (1980): str. 368.

43 Mnogi od njih morali su se zadužiti kod banaka. Dvorac, gospodarske zgrade i oranice dobio je u zakup Lajoš Gajer, a preostale su šume došle u zakup tvrtke Kartsak (Karton Sack). U toj fazi veleposjed je doživio devastaciju. Usp. Milivoj Dretar, "Prilike u kotaru Ludbreg u poratnim godinama (1918.1925.)," u Varaždin i sjeverna Hrvatska u desetljeću nakon Velikog rata: Zbornik radova sa znanstvenog skupa održanog u Varaždinu 9. studenoga 2018. godine, ur. Stjepan Damjanović i Vladimir Huzjan (Zagreb: Hrvatska akademija znanosti i umjetnosti, 2019), str. 211-212. Zahvaljujem Jadranu Jeiću na pomoći oko prikupljanja dotične literature.

44 HR-HDA-757. Plavšić, dosje Balkanska banka u vezi s inž. Nikolom Plavšićem (gradnja željeznice Vardišste-Šargan), dodatak izvješću (kut. 5).

45 Radomir Kopša, Milan Jovanović, Vladimir Stefanović, Dimitrije Milojević i Miloj M. Protić sklopili su 29. siječnja 1920. izuzetno povoljan ugovor s Ministarstvom šuma i rudnika za eksploataciju šume. Usp. HR-HDA-757. Plavšić, dosje Balkanska banka u vezi s inž. Nikolom Plavšićem (gradnja željeznice Vardište-Šargan), dodatak izvješću (kut. 5).
} 
Ugovorom od 11. svibnja 1923. Balkanska banka sklopila je posao kupnje drvene građe Frana Petrića, iz koje se imao namiriti njegov dug kod banke. Za prodaju te građe sklopila je banka ugovor s Dragom Lončarićem, prema kojem je on na dobitku prodaje participirao s 50\%. ${ }^{46}$

Jedna verzija sloma Balkanske banke prikazana je u izvještaju upravnoga odbora od 7. travnja 1925., kao i u sačuvanim dokumentima obitelji Plavšić, no oni naravno sadrže subjektivnu notu. Prema njima, ${ }^{47}$ banka je, započevši svoje poslovanje s dioničkom glavnicom od 12,500.000 dinara, naišla u početku svojega poslovanja na izuzetno povoljan odaziv ne samo od strane poslovnih partnera, nego i na vanjskom tržištu. Banka je primala razne ponude da stupi u vezu $s$ jakim inozemnim financijskim i industrijskim koncernima u Mađarskoj, Austriji i Češkoj. Povrh toga, bila joj je ponuđena i fuzija s Brodskom eskomptnom i mjenjačnom bankom, ${ }^{48}$ koja je trebala biti provedena pod zaštitom Ústředni banke českých spořitelen u Pragu. ${ }^{49}$ Te sve ponude ponukale su upravu banke da već u prvoj poslovnoj godini zaključi povišenje dioničke glavnice na $18,750.000$ dinara, ${ }^{50}$ te su novoemitirane dionice trebale biti preuzete od inozemnih grupa, koje su trebale participirati u banci. Međutim, nepovoljne prilike koje su uslijedile na novčanim tržištima Srednje Europe prouzročile su da ni jedna od tih

46 Balkanska banka kupila je od Frane Petrića $6.000 \mathrm{~m}^{3}$ jelove tesane građe, $1.500 \mathrm{~m}^{3}$ bukove građe i $1.000 \mathrm{~m}^{3}$ jelove piljene građe. Drvena građa prevožena je na Sušak na daljnju prodaju. Usp. HRHDA-757. Plavšić, dosje Balkanska banka u vezi s inž. Nikolom Plavšićem (gradnja željeznice VardišteŠargan), dodatak izvješću (kut. 5).

47 HR-HDA-757. Plavšić, dosje o likvidaciji Balkanske banke d.d. (1922-1948), izvještaj izvanredne glavne skupštine Balkanske banke od 18. travnja 1925., izvještaj upravnog odbora Balkanske banke od 7. travnja 1925. za izvanrednu glavnu skupštinu dioničara (kut. 59); dosje Balkanska banka d.d. u likvidaciji (prikaz sloma i razno) (kut. 5).

48 Brodska eskomptna i mjenjačna banka potječe od Štedne i pripomoćne zadruge u Slavonskom Brodu (upisana je 1902. u trgovački registar u Brodu). Imala je podružnice u Đakovu (od 1903.), Zagrebu (od 1911.) i Osijeku (od 1918.). Godine 1919. u brodski trgovački registar upisan je premještaj sjedišta iz Broda na Savi u Zagreb, a 1920. na glavnoj skupštini zaključena je promjena naziva (Centralna eskomptna i mjenjačna banka d.d. Zagreb). Banku su, kao ogranak (afilijacije) Hrvatske eskomptne banke Zagreb, utemeljile Ústředni banka českých spořitelen u Pragu (Središnja banka čeških štedionica), Moravská agrární a prumyslová banka u Brnu (Moravska poljodjelska i industrijska banka) i Pozemková banka u Pragu (Zemaljska banka), koje su zajedno s Hrvatskom eskomptnom bankom bile u vlasništvu većine dionica. Centralna eskomptna i mjenjačka banka d.d. Zagreb prestala je postojati 31. prosinca 1923. godine. Brisana je 1924. iz trgovačkoga registra u Zagrebu, jer je zaključila fuziju s Bankom za trgovinu, obrt i industriju d.d. u Zagrebu. Usp. Lajnert, "Arhivistički prikaz," str. 616, 619620, 640; Hanel, Compass: Finanzielles Jahrbuch 1925, str. 169-170.

49 Ústředni banka českých spořitelen u Pragu (Središnja banka čeških štedionica Prag) protokolirana je 1903. godine. Njezin pridruženi novčarski zavod (ogranak, afilijacija) bila je Centralna eskomptna i mjenjačna banka d.d. Zagreb. Usp. Rudolf Hanel, Compass: Finanzielles Jahrbuch 1923: Band II: Tschechoslovakei (Wien: Compassverlag, 1923), str. 57-60.

50 U trgovačkom registru u Zagrebu upisano je 1922. da je Balkanska banka izdala 187.500 dionica po 100 dinara, tako da je potpuno uplaćeno 18,750.000 dinara dioničke glavnice. Usp. HR-HDA-152. SFD, dosje Balkanska banka d.d. Zagreb, odluka Kr. sudbenoga stola kao trgovačkoga suda u Zagrebu od 2. lipnja 1922. (kut. 302). 
kombinacija nije mogla biti ostvarena. Fuzija s Brodskom eskomptnom i mjenjačnom bankom nije provedena usprkos već utanačenoga i od Ústředni banke českých spořitelen odobrenoga međusobnoga ugovora ${ }^{51}$ jer je, uslijed nelojalnosti nekih članova uprave Brodske eskomptne i mjenjačne banke, taj zavod u zadnji čas priključen koncernu jednoga drugoga zagrebačkog novčanog zavoda. Iako je uprava banke uslijed već vođenih pregovora sa spomenutim grupama bila u

51 Dušan Plavšić uputio je 7. svibnja 1922. Lavoslavu Singeru, potpredsjedniku Centralne eskomptne i mjenjačne banke d.d. Zagreb pismo u vezi eventualne fuzije Balkanske banke i Centralne eskomptne i mjenjačne banke. Plavšić ga obavještava da je egzekutivni odbor njegove banke sa zadovoljstvom uzeo do znanja stav češke grupe vezane uz Centralnu eskomptnu i mjenjačnu banku o navedenoj fuziji, kako je dogovoreno u utanačenju ravnateljstva Singerove banke i čeških zavoda. Plavšić je naglasio da i njegova banka želi fuziju provesti na temelju sporazuma koji je on dogovorio sa Singerom. Istovremeno obavještava Singera da u tome trenutku nisu mogli staviti konkretnu ponudu, nego da će to učiniti za 14 dana, kad su trebali biti u stanju udovoljiti svim uvjetima fuzije. Jedan od glavnih uvjeta bilo je preuzimanje nove emisije dionica Centralne eskomptne i mjenjačne banke u vrijednosti od 25,000.000 kruna, čime bi kapital Singerove banke bio povišen na 100,000.000 kruna. Budući da je bilo u postupku povećanje kapitala Balkanske banke na 100,000.000 kruna (emisija od 50,000.000 kruna) te je postupak trebao trajati do konca svibnja 1922., to je Plavšićeva banka tek za 14 dana mogla imati jasnu sliku o uspjehu te emisije i jamstvo da se može izlučiti odgovarajući iznos za provedbu supskripcije dionica Singerove banke. Plavšić naglašava da njegova banka nije mogla prije toga roka riješiti ni personalna pitanja o popuni ravnateljstva. Ravnateljstvo se je sastojalo od 12 osoba, od kojih u tom trenutku ne bi nikoga mogli primorati da odstupi. Budući da su njihova pravila predviđala ravnateljstvo od najviše 18 osoba, za udovoljenje Singerovih želja morali bi provesti promjenu pravila. Kako je uprava Balkanske banke zazirala od prevelikoga ravnateljstva, Plavšić je tražio Singera da pristane na to da mu se u tadašnjem ravnateljstvu prepusti 7 mjesta, i to 3 za Čehe, a 4 mjesta za članove Singerove banke. Uprava Balkanske banke bila je zainteresirana da u njihovo ravnateljstvo uđe Singer, Pilepić, Grünwald i Kukuljević. Plavšić je nudio Singeru i 3 mjesta u nadzornom odboru Balkanske banke. Istovremeno je naglasio da nije opravdano da obje banke imaju u ravnateljstvu isti broj članova. Kada bi Balkanska banka preuzela 25,000.000 kruna dionica Centralne eskomptne i mjenjačne banke, tada bi nakon fuzije razlika u kapitalu bila takva da bi Balkanska banka, odnosno njezina poslovna grupacija od ukupnih $200,000.000$ kruna reprezentirala 125,000.000 kruna, a Singerova grupacija samo 75,000.000 kruna. Prema tom bi razmjeru kapitala Centralna eskomptna i mjenjačna banka trebala dobiti 7 mjesta, a Balkanska banka 12. Mjesto predsjednika i jednoga podpredsjednika pripalo bi nakon fuzije grupaciji oko Balkanske banke, a Singerovoj bi grupaciji pripalo drugo mjesto podpredsjednika. Plavšić je poručio Singeru da bi Balkanska banka u roku od 14 dana mogla preuzeti jamstva za provedbu fuzije, ako se on složi s tim propozicijama. Iz pisma Dušana Plavšića upućenoga 7. svibnja 1922. Matiji Hercegu, podpredsjedniku Balkanske banke, vidljivo je da je za fuziju s Centralnom eskomptnom i mjenjačnom bankom ozbiljno bila zainteresirana i Banka za trgovinu, obrt i industriju (Trgo-banka) te da je generalni ravnatelj te banke Leo Kronfeld pokušavao ostvariti kontakte u tom pogledu. To je Plavšiću priznao i sam Lavoslav Singer, podpredsjednik Centralne eskomptne i mjenjačne banke d.d. Zagreb. Jedna grupacija vezana za Centralnu banku bila je mišljenja da treba dati prednost Leu Kronfeldu, a ne Plavšiću, jer su u toj fuziji vidjeli za sebe bolji materijalni uspjeh. Naime, Trgo-banka bila je stari novčarski zavod $s$ velikim financijskim rezervama i velikom vrijednošću dionica. Iz pisma upućenoga 11. svibnja 1922. Matiji Hercegu, podpredsjedniku Balkanske banke, koji se je tada nalazio na nekim pregovorima u Beču, vidljivo je da je Plavšić kalkulirao. On je izrazio svoje mišljenje da bi se fuzija morala provesti, osim ako bi Hercegovi pregovori u Beču uspješno završili, pa bi ta fuzija postala bespredmetna. Ipak, Plavšić je na kraju pisma donio zaključak da, kada bi banka i dobila mnogo novaca iz inozemstva, nije trebalo posve napustiti kombinaciju s Centralnom eskomptnom i mjenjačnom bankom. U tom slučaju Plavšić je predložio da im se preuzimanjem 25,000.000 kruna njihovih dionica poveća kapital i time uđe u njihovu upravu. Time bi se stvorila interesna zajednica iz koje bi kasnije mogla uslijediti fuzija uz mnogo povoljnije uvjete. Usp. HR-HDA-757. Plavšić, dosje Balkanska banka-inozemne veze (kut. 5). 
mogućnosti provedbu sklopljenih dogovora tražiti sudbenim putem, to svoje pravo nije iskoristila jer je željela izbjeći spor, koji bi se djelomično morao voditi $\mathrm{u}$ inozemstvu te koji bi banku doveo u sukob $s$ drugim novčarskim zavodima $\mathrm{u}$ zemlji. Dionice, koje su tom prilikom ostale nesupskribirane, ${ }^{52}$ preuzeo je sindikat članova uprave, koji je te dionice pokrio kreditom kod Zagrebačke banke u Zagrebu u uvjerenju da će povoljan razvitak zavodskoga poslovanja omogućiti da te dionice budu sukcesivno plasirane te time rasteretiti sindikat. ${ }^{53}$ Poslovanje zavoda razvijalo se je pozitivno, pa je banka internom bilancom, koja je sastavljena 31. prosinca 1922., mogla ustanoviti da ima obračun na svakoj strani bilance od preko 90,000.000 dinara te da su banci povjerena tuđa sredstva iznosila oko 45,000.000 dinara, od kojih je bilo preko 7,000.000 dinara uloga na knjižice. Međutim, kao što je već rečeno, predsjednik banke Dušan Plavšić bio je pozvan za pomoćnika ministra financija. Kako je vlada kojoj je Plavšić pripadao u prosincu 1922. dala ostavku, to je uslijed tadašnjih političkih prilika nastala novinska kampanja bila uperena i protiv Balkanske banke. Najperfidniji bio je list Obzor, u kojem je uspoređivano kašnjenje plaćanja Balkanske banke s tadašnjim aktualnim slučajem kraha tršćanske tvrtke Hacker i Kraus, tako da je javnost uslijed te usporedbe mogla povjerovati da je banka ne samo kasnila s plaćanjem, nego da je pritom bila i pasivna, te da ne može plaćati svoje obveze. Prema podatcima iz fonda Plavšić, nastojanje u listu Obzor bilo je uništenje banke njihovih političkih protivnika. ${ }^{54}$ Osim u listu Obzor o Plavšiću kao lošem pomoćniku ministra financija i o skandaloznom poslovanju njegove Balkanske banke kontinuirano je pisano i u listu Hrvat. U njemu je između ostaloga navedeno da je Plavšić kao tzv. "direktor zajma”, odnosno njegova Demokratska stranka odgovorna za sklapanje nepovoljnoga dolarskoga zajma koji je državi donio samo veliku štetu i veliki dug s kamatama. ${ }^{55}$ Iako je Plavšić prigodom polaska na tu

52 Supskripcija (lat.), potpisivanje imena za preuzimanje dionica, obveznica i sl.; supskribirati, potpisati. Usp. Klaić, Rječnik stranih riječi, s. v. supskripcija. Dionice su, znači, ostale nepotpisane.

53 Zagrebačka banka d.d. Zagreb potječe od Hrvatske zagorske štedne i predujamne zadruge u Zagrebu. Temeljem zaključka glavne skupštine u trgovačkim registru u Zagrebu upisana je 1919. promjena naziva u Hrvatska zagorska banka d.d., a 1922. u Zagrebačka banka d.d. u Zagrebu. Likvidacija banke, zaključena 1924., provedena je 1947. godine. Usp. Lajnert, "Arhivistički prikaz," str. 648-649, 712-713.

54 HR-HDA-757. Plavšić, dosje Balkanska banka u vezi s inž. Nikolom Plavšićem (kut. 5). Dokument je bez potpisa i datuma, tako da nije razvidno tko ga je i kada napisao.

55 Prema pisanju tih novina Plavšićevim "dizanjem dinara" na račun državnih dolara uveliko se je pomogla Balkanska banka, a već kod iskazivanja dioničke glavnice viđen je "pravi balkanizam”. Od iskazanih 50,000.000 dinara glavnice, bilo je uplaćeno oko 7,500.000, a provedeno kroz knjige 18,750.000. Uloga je bilo 30,000.000, a nepokrivenih deviza 27,000.000, u kojoj su svoti bili angažirani gotovo svi zagrebački zavodi. Rukovodstvo banke nudilo je $100 \%$ isplate, a sami su vjerovali svojemu zavodu toliko da nisu htjeli dati garanciju za tu isplatu. Umjesto da pokrivaju devize, oni su radili s tim novcem. Kako je kod toga čisto "bankovnoga" posla odlučivala politika, vidi se po tom što je državni čekovni ured banci davao novaca, a drugim ga je zavodima u Zagrebu ustezao. Kad je banka kod zagrebačkoga Sudbenoga stola zatražila nagodbu van stečaja, stečajnim povjerenikom postao je sudac Maričić - demokrat, a stečajnim upraviteljem Srđan Budisavljević, glava zagrebačkih demokrata, "desna i to bijesna ruka" Svetozara Pribičevića, kako je napisano u listu Hrvat. Riječ je o čovjeku koji se odvjet- 
dužnost dao ostavku na svoje mjesto predsjednika u banci, a nakon pada vlade na to se mjesto nije vratio, ${ }^{56}$ ta je novinska kampanja ipak ostavila teške posljedice na banku. Prema sačuvanim dokumentima obitelji Plavšić, ${ }^{57}$ slučaj Balkanske banke imao je čisto politički karakter. Osnivači i upravitelji banke pripadali su Demokratskoj stranci, pa je tako i njezin predsjednik Dušan Plavšić bio jedan od istaknutih stranačkih ljudi. S druge strane, inicijatori hajke na Balkansku banku u Zagrebu pripadali su Hrvatskomu bloku, ${ }^{58}$ a u Beogradu Radikalnoj stranci. Tako je zagrebački blokovski tisak, potpomognut financijski od strane blokovskih banaka, ${ }^{59}$ inscenirao prepad na Balkansku banku, a u Beogradu taj je posao

ničkim poslovima uopće nije bavio. Banka je svaljivala krivicu na novinsku kampanju, zbog koje nije mogla popraviti svoje novčane neprilike. U listu Hrvat s pravom se pita: »A tko je onda kriv da je banka uopće došla u te neprilike? « Inače, banka je golemim sumama novca pomagala Organizaciju jugoslavenskih nacionalista (Orjuna), tako da je uslijed njezina kraha u Zagrebu prestalo izlaziti orjunsko glasilo Zagrebačka orjuna. Poslovanje Balkanske banke čitavo je vrijeme bilo obilježeno skandalima. Tako je 7. travnja 1923. ukraden novac iz bančine blagajne, za što su optuženi trojica podvornika banke: Milan Cvek, Stjepan Martek i Mirko Špišić. Postupak pred Sudbenim stolom započeo je 15. studenoga 1923. List Hrvat na kraju zaključuje da "ono što je građeno samo na politici, a ne i na zdravoj privredi, to stradava i zbog nesolidnosti i zbog politike, čim ona dobije novu haljinu«. Usp. Dolarski zajam, Hrvat 5, br. 852 (8. siječnja 1923): str. 2; "Riječ" i Eskomptna banka, Hrvat 5, br. 880 (10. veljače 1923): str. 3; Politika u privredi: Slom Balkanske banke i Orjune, Hrvat 5, br. 1006 (16. srpnja 1923): str. 2-3; Hacker i Kraus u Zagrebu: Slom Balkanske banke, Hrvat 5, br. 1007 (17. srpnja 1923): str. 3; Tko je dobio stečaj "Balkan. banke", Hrvat 5, br. 1008 (18. srpnja 1923): str. 3; Krađa u Balkanskoj banci pred sudom, Hrvat 5, br. 1110 (16. studenoga 1923): str. 2; Hrvat 5, br. 1111 (17. studenoga 1923): str. 2.

56 Izvještaj upravnoga odbora banke od 7. travnja 1925. kaže da se Plavšić nakon pada Vlade nije vratio na mjesto predsjednika banke, ali desetak dana kasnije u izvještaju s izvanredne glavne skupštine dioničara banke od 18. travnja 1925. on se navodi kao predsjednik banke. Usp. HR-HDA-757. Plavšić, dosje: spisi o likvidaciji Balkanske banke d.d. (1922-1948), izvještaj izvanredne glavne skupštine Balkanske banke od 18. travnja 1925., izvještaj upravnoga odbora Balkanske banke od 7. travnja 1925. za izvanrednu glavnu skupštinu dioničara (kut. 59).

57 HR-HDA-757. Plavšić, dosje Balkanska banka d.d. u likvidaciji (prikaz sloma i razno) (kut. 5).

58 Hrvatski blok bio je koalicija hrvatskih političkih stranaka utemeljenih na državotvornim programima. Savez je sklopljen 1921., a činili su ga Hrvatska republikanska seljačka stranka, Hrvatska zajednica i Hrvatska stranka prava, $s$ ciljem ujedinjenja svih hrvatskih političkih snaga u borbi protiv centralizma i nametanja velikosrpske hegemonije. Zajedničko glasilo te tri hrvatske političke stranke bio je časopis Hrvat. "Hrvatski blok," u Hrvatska enciklopedija: 4: Fr-Ht, ur. Dalibor Brozović (Zagreb: Leksikografski zavod Miroslav Krleža, 2002), str. 734; Hrvoje Matković, "Stjepan Radić i Hrvatski blok," Radovi 32-33 (2000): str. 268.

59 U citiranom dokumentu iz fonda Plavšić (bez potpisa i datuma, pisan pisaćim strojem na ćirilici) koji govori o likvidaciji Balkanske banke ne spominje se koje su to blokovske banke. Usp. HRHDA-757. Plavšić, dosje Balkanska banka d.d. u likvidaciji (prikaz sloma i razno) (kut. 5). No, časopis Riječc, koji je navodno financirala Balkanska banka, tvrdio je u svojim napisima da je Hrvat bio u službi Hrvatske eskomptne banke te da ga je ona financirala. U listu Hrvat to je opovrgnuto. Riječ je upriličila hajku na Hrvatsku eskomptnu banku ne bi li tako opravdala krah »svoga financijskog genija« Dušana Plavšića. No, pokušaj da politika preko medija kontrolira novčarski sustav nije ništa novoga. Čak je i Hrvat tvrdio da je svakomu poznato da je »kod nas u novčarskim poslovima politika imala svoje prste«. Pri tom se nije pazilo koliko će štete nastati u slučaju neistinitih vijesti. Bilo je poznato kako su stanoviti politički krugovi napadali neke jače novčarske zavode te su svom silom htjeli da se u njihovo poslovanje umiješa i državna vlast. Napadane su Hrvatska sveopća kreditna banka, Hrvatska eskomptna banka i dr. Napose je na potonju, nakon kraha tršćanske tvrtke Hacker i Kraus, vođena prava hajka i u Zagrebu i 
nastavljen od strane tiska Radikalne stranke i tiska na koji su radikali imali bitan utjecaj. U Zagrebu je banka bila trn u oku pripadnicima Hrvatskoga bloka jer su u njezinoj upravi sjedili Hrvati unitaristi, ${ }^{60}$ a u Beogradu je svu kampanju protiv banke inaugurirao tadašnji radikalni ministar financija Milan Stojadinović, ${ }^{61}$ koji je davao i sve potrebe informacije. On je od dana preuzimanja dužnosti ministra kontinuirano više od pola godine napadao bivšega demokratskoga ministra financija Kostu Kumanudija, ${ }^{62}$ a još više njegova pomoćnika Dušana Plavšića. U Zagrebu su alarmantne vijesti o insolventnosti Balkanske banke imale za cilj da ulagače natjeraju na podizanje svojega novca. U roku od nekoliko mjeseci morala je banka raznim vjerovnicima, poglavito drugim bankama, iz tekućih računa vratiti oko 20,000.000 dinara. Taj zahtjev na mobilnost po banci plasiranih novčanih sredstava u vrijeme teške financijske krize primorao je upravu banke na drastične mjere, jer je uslijed tih zahtjeva cjelokupno poslovanje došlo u vrlo tešku situaciju. Banka je morala ubrzati promet sredstava što je više moguće, a to se je poglavito moglo postići u deviznom prometu. Uslijed toga glavnu brigu posvetila je razvitku te grane poslovanja. Prema mišljenju upravnoga odbora, banka je kod toga nastojanja vodila najveću brigu o tom da svoje transakcije uperi na snaženje dinara, čime je stajala u opreci s čitavim tržištem, koje je imalo tendenciju iskorištavanja rastućih deviznih tečajeva, koji su sprječavali stabilizaciju tečaja dinara. Banka je forsirala prodaju dolarskih čekova, pokrivajući ih devizama (Zürich i London), koje su uz tzv. cabel doznaku u New York trebale osiguravati potrebnu vrijednost iz koje su se imali iskupiti prodani čekovi pri prezentaciji u New Yorku. ${ }^{63}$ Sukcesivnom stabilizacijom i poboljšanjem tečaja dinara trebale

\footnotetext{
u Beogradu. Usp. "Riječ" i Eskomptna banka, Hrvat 5, br. 880 (10. veljače 1923): str. 3; Politika u privredi, Hrvat 5, br. 1006 (16. srpnja 1923): str. 2.

60 Plavšić je bio pristaša unitarne jugoslavenske ideje. Usp. Kolar, "Buran život dr. Dušana Plavšića," str. 134. U jednom dokumentu iz fonda Plavšić (bez potpisa i datuma, pisan pisaćim strojem na ćirilici) koji govori o likvidaciji Balkanske banke doslovno piše: „Što su srbožderske banke sa svojim listovima navalile na B. b. u čijoj upravi sjede Hrvati srbofili, nije ni malo čudo prema današnjem raspoloženju koje vlada u Hrvatskoj.« Usp. HR-HDA-757. Plavšić, dosje Balkanska banka d.d. u likvidaciji (prikaz sloma i razno) (kut. 5).

${ }_{61}$ Radikal Milan Stojadinović bio je ministar financija 1922.-1935.

62 Kosta Kumanudi bio je ministar financija 1921.-1922.

${ }^{63}$ Temeljem ovlasti Narodne banke Kraljevine SHS br. 35.223 od 1. lipnja 1922., Balkanska banka se je bavila arbitražnim poslovima i jako ih je razvila. Arbitražno poslovanje obuhvaćalo je sve transakcije $s$ inozemnim platežnim sredstvima. Išlo se je za tim da se inozemna platežna sredstva, kojih nije bilo na tržištu, nabavljaju, tj. pokrivaju onim inozemnim platežnim sredstvima koja su bila ponuđena na tržištu, a za koja nije bilo trenutačne potrebe. Ako se je primjerice na burzi u Zagrebu ukazala velika potreba za francuskim francima, a ponude u tim devizama nije bilo, dok je istovremeno bila velika ponuda u engleskim funtama, koje nisu bile tražene na tržištu, onda su arbitražni zavodi preuzimali te raspoložive funte da njima tržištu osiguraju francuske franke, koji su bili traženi. Transakcija je bila uspješna ako je tečaj engleskih funti u Parizu omogućavao da se u Parizu nabavljeni franci mogu u Zagrebu plasirati s nekim dobitkom. Dobitak arbitražnoga poslovanja ležao je dakle u izravnanju burzovnih tečajeva inozemnih platežnih sredstava na domaćim burzama i u održavanju tečaja dinara na stranim burzama. Dobitak za Balkansku banku ležao je u tom da si arbitražom stvori najpovoljniji tečaj
} 
su te bančine transakcije konačno završiti dobitkom za nju. Problemi $s$ bančinim sredstvima trebali su biti olakšani s realizacijom velikoga potraživanja, što ga je banka imala protiv svojega najvećega dužnika, Građevnoga poduzeća "ing. Nikola Plavšić” za gradnju željeznice Vardište-Šargan, koji je posao banka kao partner financirala. U prvoj polovici 1923. godine imala je banka protiv države iz toga naslova potraživanje od skoro 20,000.000 dinara. ${ }^{64}$ Međutim, sva nastojanja banke da to potraživanje realizira, ostala su bezuspješna, jer je navedena građevna tvrtka ušla u spor s državom, koji joj je onemogućio isplatu njezinih obveza. Banka je stoga bila primorana otpisati veliki dio svoje tražbine. Mišljenje upravnoga odbora banke bilo je da bi se normalnim razvojem prilika zavod izvukao iz tih neprilika, da se koncem lipnja i početkom srpnja 1923. nije dogodilo nešto što je potpuno poremetilo bančine financijske snage. Naime, od 15. lipnja do 10. srpnja 1923. kupila je banka na burzi od raznih novčanih zavoda u Zagrebu i Beogradu ukupno 945.000 švicarskih franaka, koji su prema ondašnjem tečaju vrijedili oko 16,000.000 dinara. Iako je banka tu kupovinu na vrijeme platila gotovim novcem, odobrenja tih švicarskih franaka nisu uslijedila. Uslijed toga pao je čitav niz od banke prodanih dolarskih čekova u New Yorku pod protest, ${ }^{65}$ jer

za pokriće prodanih deviza te da kod toga iskoristi ne samo razlike između tečajeva iste valute na raznim europskim tržištima, nego da iskoristi i vrijeme između prodaje deviza i termina u kojem su te devize trebale biti plaćene na inozemnom tržištu. Banka je uočila da je na burzama u Zagrebu i Beogradu konstantno velika potreba za dolarima te da se povoljna arbitraža može provesti između tržišta New Yorka, Züricha i Zagreba, odnosno Beograda. Usp. HR-HDA-757. Plavšić, dosje Balkanska banka, Kako je nastao slom Balkanske banke? (kut. 27).

64 U Beogradu je izdano rješenje Ministarstva saobraćaja po kojem se banci kao financijeru gradnje željezničke pruge Užice-Vardišste zamrzava kapital od oko 23,000.000 dinara na neodređeno vrijeme. Usp. HR-HDA-757. Plavšić, dosje Balkanska banka d.d. u likvidaciji (prikaz sloma i razno) (kut. 5).

65 S obzirom na činjenicu da neke zagrebačke banke nisu na vrijeme pokrile čekove u visini od 800.000 švicarskih franaka, iako su ih za gotovinu prodale Balkanskoj banci. Čekovi su služili za pokriće dolarskih čekova banke, pa je razumljivo da su oni morali biti protestirani. Na taj je način u prvi mah izgledalo kao da Balkanska banka radi s velikim sumama u dolarskim čekovima za koje nije imala pokriće. Ipak, tijekom vremena stizali su izvještaji o urednom pokriću dolarskih čekova Balkanske banke, da bi na kraju došao izvještaj o pokriću na preko 11.000.000 dinara, što je činilo veći dio sume koja je bila u pitanju. Neosporna je činjenica da se Balkanska banka koristila vremenom koje je bilo potrebno da ček poštom stigne u New York, a da je njegovo pokriće javljala u Ameriku "kablom". U državama zapadne Europe, gdje su postojali zakoni o poslovanju s čekovima, takve manipulacije nisu bile dopuštene, a poslovanje čekovima u Kraljevini SHS, gdje nije postojao zakon o čekovima, bilo je proizvoljno. Balkanska se banka prema tome nije ogriješila ni o jedan zakon, nego se je poslužila uzancama svih zemalja koje nisu imale zakon o čekovima. Učinila je to tim prije što je postojalo jedno ministarsko naređenje po kojem je arbitražna prodaja za dolarske čekove naknadno pokrivana "kablom". Visina sume za tada još nepokrivene čekove Balkanske banke nije premašivala njezin redovan dnevni opticaj, koji je tada silom prilika morao biti obustavljen. Prema tome, istragom je utvrđeno da je alarm prema poluslužbenim informacijama Ministarstva financija bio lažan kada je govorio o nepokrivenim sumama koje su prelazile iznos cjelokupnoga bančinoga imetka. Iako je zbog istrage poslovanje banke što se tiče isplata bilo obustavljeno, nepokrivena suma bila je tek u visini njezina dnevnoga prometa ili jednaka isplaćenoj sumi uloga na šalteru prvoga dana alarma. Usp. HR-HDA-757. Plavšić, dosje Balkanska banka d.d. u likvidaciji (prikaz sloma i razno) (kut. 5). Treba napomenuti da su se i ranije događali sporadični protesti dolarskih čekova, uslijed nepristiglih doznaka, i to od strane Prve hrvatske štedionice, koja je zakas- 
nabavljano pokriće nije pravodobno stiglo. Banka je bila primorana da 10. i 12 . srpnja 1923. kod Zagrebačke burze podigne proteste, koji su kod Obraničkoga suda Zagrebačke burze za robu i vrednote bili upisani pod br. 127, 132, 133, 134, 135, 136, 137 i 138. Banka nije imala raspoloživih novčanih sredstava da pokrije svoje čekove, pa je uslijed toga morala obustaviti čitavo devizno poslovanje dok ne ustanovi razloge, koji su doveli do protesta tolikoga broja njezinih čekova. Međutim, i daljnji bančini čekovi bili su stavljeni u promet koje banka više nije bila kadra pokriti. Zbog udaljenosti i dugotrajnosti poštanskoga prometa između New Yorka i Zagreba, faktičko stanje bančinih nepokrivenih obveza nije moglo biti odmah ustanovljeno, pa je banka, vjerujući da njezina imovina dostaje za pokriće svih preuzetih obveza, pristupila vjerovnicima da postigne kratkotrajni moratorij za uređenje svojih prilika. Banka kod svojih vjerovnika nije naišla ni na kakvu susretljivost, pa je uslijed novinske kampanje bila primorana zatražiti zaštitu suda. ${ }^{66}$ Taj postupak uprave banke onemogućio je daljnju kampanju protiv nje. No pored svega toga, ranije alarmantne vijesti koje su govorile o daleko većim sumama nepokrivenih dolarskih čekova nego što je bio iznos svih bančinih potraživanja, zatim naglo vađenje uloga uplašenih klijenata i u zagrebačkom tisku objavljena izjava generalnoga ravnatelja grofa Lubienskog, po kojoj on nema više veze $s$ Balkanskom bankom - sve zajedno imalo je za posljedicu da je morala prestati normalna cirkulacija kapitala u banci te da se zbog toga tijekom vremena nisu mogle provesti razne platežne transakcije. Interesantno je da je baš na 16. srpnja 1923., kada je banka obustavila svoje poslovanje, Ministarstvo saobraćaja prekinulo građevni ugovor $s$ tvrtkom Nikole Plavšića, čime je banci oduzeta zadnja nada da dođe do jedne od svojih najvećih tražbina, pa njezinoj upravi nije preostalo ništa drugo nego da zatraži otvaranje postupka za prinudnu nagodbu. ${ }^{67} \mathrm{Na}$ zahtjev vjerovnika sud je svu vlast prenio na vjerovnički

nila oko 5 tjedana, i Hrvatske eskomptne banke, koja je zakasnila 30 dana. Te su doznake, prema ustaljenim uzancama, trebale stići bančinoj vezi u Zürichu šesti dan. Usp. HR-HDA-757. Plavšić, dosje Balkanska banka, Kako je nastao slom Balkanske banke? (kut. 27).

${ }^{66}$ Represalijama koje je ministar financija Stojadinović pokušao primijeniti prilikom udara na banku iz Zagreba postignut je negativan utjecaj na bančino poslovanje. Lažne vijesti poluslužbenoga karaktera od strane Ministarstva financija, kojima je javljeno da će Plavšić biti uhapšen a banka zapečaćena, pobudile su vjerovanje kod dijela javnosti da tu ima nečega kriminalnoga. Odmah na početku novinarske kampanje, upravni je odbor Balkanske banke prijavio cijelu stvar nadležnomu sudu s izjavom da ne samo banka, nego i privatni imetci članova uprave garantiraju komitentima isplatu bančinih obveza u punoj vrijednosti s odgovarajućim kamatama, a dioničarima potpunu vrijednost uplaćenih dionica. Time je stavljena ne samo banka, nego i njezini komitenti pod zaštitu suda. Usp. HR-HDA-757. Plavšić, dosje Balkanska banka d.d. u likvidaciji (prikaz sloma i razno) (kut. 5).

${ }_{67}$ Balkanska banka d.d. Zagreb obavijestila je 24. studenoga 1923. Kr. financijsko ravnateljstvo u Zagrebu da se nalazi u postupku prinudne nagodbe, da joj je odlukom nagodbenoga suda br. 42.318 gr. N-8-1923 od 18. rujna 1923. zabranjeno poslovanje te da je od otvorenja nagodbenoga postupka, tj. od 18. srpnja 1923. obustavila svako poslovanje. S obzirom na to da je ravnateljstvo Balkanske banke unatoč povedenoga postupka za prinudnu nagodbu izvan stečaja činilo radnje kojima je pogodovalo pojedinim vjerovnicima i dužnicima, to je 18. rujna 1923. nagodbeni sudac Kr. sudbenoga stola u Zagrebu Vaić zabranio Balkanskoj banci, odnosno njezinu ravnateljstvu, da obavlja bilo pravne bilo 
odbor i nagodbenoga upravitelja Srđana Budisavljevića. Uprava banke više nije mogla provoditi daljnje dispozicije ni pravne radnje, te je bila u svemu ovisna o mišljenju vjerovničkoga odbora i nagodbenoga upravitelja. Pokazalo se je da je bilo izuzetno teško ukloniti razlike koje su se pojavile između uprave banke i vjerovničkoga odbora o daljnjem vođenju poslovanja. Uprava banke ponudila je nagodbenu kvotu od $100 \%$ vjerovničkih potraživanja zajedno s kamatama, no vjerovnici, koji su nepovoljnije procijenili imovinu banke, nisu prihvatili tu ponudu. Tek nakon više od pola godine postignut je sporazum, na temelju kojega je sudu podnesena nova ponuda, koja je omogućila da se postupak prinudne nagodbe konačno provede. Prema toj ponudi vjerovnicima su trebale biti plaćene sljedeće kvote u roku od dvije godine: vjerovnicima iz poslovanja ukupno 50\% zajedno s $6 \%$ kamata, a vjerovnicima iz uložnoga posla $70 \%$ zajedno s $6 \%$ kamata. Od preostale imovine, tim posljednjima trebalo je biti isplaćeno još daljnjih 30\%. Uprava banke stajala je na gledištu da bančina imovina te oprezno provedena realizacija nekih većih poslova omogućuje provedbu nagodbe sa stopostotnom kvotom. Međutim, kako je upravi banke bila po sudu uzeta mogućnost odluke, to banka nije mogla pristupiti ni iskorištavanju šumskoga posla Pesač ni provedbi posla Parcelacija Ludbreg, koji su iziskivali daljnje investicije. Tako je šumski posao Pesač više od godinu i pol stajao posve neiskorišten, a parcelacijski posao Ludbreg banka je morala prodati da spasi uložene investicije i kamate na njih. Istovremeno su neki dužnici banke, uslijed posljedica novčarske krize, postali loši platiše te zatražili nagodbu. Pored svega toga, uprava banke bila je uvjerena da će bančina imovina omogućiti posvemašnju provedbu njezinih preuzetih nagodbenih obveza, pa su radi toga članovi uprave Dušan Plavšić, Matija Herceg, Stanislav I. Lubienski, Amon Rukavina, Vinko Zlatarić, Valerij Riesner i Franjo Ottenfels preuzeli jamstvo pologom efektivnih garancija u ukupnom iznosu od 8,000.000 dinara. Tako je konačno uspjelo izglasavanje prinudne nagodbe na ročištu od 23. listopada 1924., te je odluka o tom od Sudbenoga stola kao nagodbenoga suda objavljena 10. studenoga 1924. pod br. 58.091 gr. N 16-23. ${ }^{68}$ Ta nagodba postignula je svoju pravomoćnost 10. ožujka 1925. ,

\footnotetext{
druge radnje u ime banke dok god traje postupak. Povjereno je Nagodbenomu odboru vjerovnika Balkanske banke nadziranje nagodbenoga upravitelja Srđana Budisavljevića, koji se je imao strogo držati uputa koje mu je davao navedeni Odbor. Naloženo mu je da u ime Balkanske banke poduzme pravne radnje koje su bile potrebne za održavanje i očuvanje bančine imovine te da u tu svrhu poduzme sve potrebne korake za utjerivanje tražbina Balkanske banke, s time da se u tom pogledu strogo drži zaključaka nagodbenoga odbora. O tim odlukama nagodbeni sudac Vaić obavijestio Stjepana Posilovića, odvjetnika iz Zagreba kao predsjednika Nagodbenoga odbora, Srđana Budisavljevića, odvjetnika iz Zagreba kao nagodbenoga upravitelja, i Dušana Plavšića, glavnoga ravnatelja Balkanske banke. Usp. HR-HDA-152. SFD, dosje Balkanska banka d.d. Zagreb, dopis nagodbenoga suca Kr. sudbenoga stola u Zagrebu od 18. rujna 1923. i dopis Balkanske banke upućen 24. studenoga 1923. Kr. financijskomu ravnateljstvu u Zagrebu (kut. 302).

$68 \mathrm{Na}$ molbu Balkanske banke d.d. od 22. prosinca 1923., kojom je zatraženo otvaranje postupka o prinudnoj nagodbi izvan stečaja, Kraljevski sudbeni stol kao trgovački sud u Zagrebu donio je 10. stu-
} 
pa su se od toga dana računali i rokovi za isplatu pojedinih ustanovljenih kvota. ${ }^{69}$ $\mathrm{Na}$ temelju te prinudne nagodbe Balkanska banka trebala je zaključiti likvidaciju, koja je trebala biti provedena na način da u likvidacijski odbor bude izabrano 6 osoba, od kojih je 4 trebao odrediti vjerovnički odbor, a 2 garancijski sindikat banke za provedbu prinudne nagodbe. Faktična provedba likvidacije trebala je posebnim sporazumom biti predana podružnici Engleske trgovinske banke u Zagrebu, ${ }^{70}$ Jugoslavenskoj banci d.d. Zagreb i Centralnoj banci za trgovinu, obrt i industriju u Zagrebu. ${ }^{71}$ Upravi banke uspjelo je za provedbu te likvidacije 5. prosinca 1924. dogovoriti sporazum prema kojem su ti zavodi izjavili da neće praviti smetnje te da će odobriti da se vjerovnici i uložitelji banke namire i prije dospijeća njihovih dijelova kvota, ako bi to bilo u interesu banke te ako bi to dopuštao obzir prema ostalim vjerovnicima. ${ }^{72}$

denoga 1924. odluku kojom je potvrđena ponuđena prinudna nagodba izvan stečaja. Usp. Oglas, NN 269/1924.

69 Dana 11. ožujka 1925. nagodbeni sudac Roko Maričić u ime Kr. sudbenoga stola u Zagrebu obznanio je da je završen postupak u prinudnoj nagodbi izvan stečaja, koji je bio otvoren na molbu Balkanske banke odlukom br. 58.804 gr. od 14. ožujka 1924., nakon što je donesena odluka Kr. sudbenoga stola u Zagrebu br. 58.091 od 10. studenoga 1924. kojom je potvrđena nagodba postala pravomoćna s danom 10. ožujka 1925. Usp. Stečaji: Oglas, NN 60/1925.

70 Engleska trgovinska banka osnovana je 1906. sa sjedištem u Londonu. Od 1920. počela je djelovati u Kraljevini SHS (podružnica u Beogradu.). Kr. sudbeni stol kao trgovački sud u Zagrebu dao je 30. prosinca 1922. na znanje da je u trgovačkom registru upisana podružnica Engleske trgovinske banke u Zagrebu. Glavno sjedište društva u Kraljevini bilo je u Beogradu. Usp. Lajnert, "Arhivistički prikaz," str. 630-631.

${ }^{71}$ Centralna banka za trgovinu, obrt i industriju osnovana je 1906. i upisana u trgovački registar u Zagrebu kao Banka za trgovinu, obrt i industriju d.d. u Zagrebu. Osnovana je temeljem drušstvenih pravila prihvaćenih na konstituirajućoj glavnoj skupštini od 8. veljače 1906. Godine 1924. zaključena je njezina fuzija s Centralnom bankom d.d. u Zagrebu i Centralnom eskomptnom i mjenjačkom bankom d.d. u Zagrebu. Centralna banka d.d. Zagreb i Centralna eskomptna i mjenjačka banka d.d. Zagreb prestale su postojati 31. prosinca 1923. godine. Banka za trgovinu, obrt i industriju d.d. Zagreb promijenila je ime u Centralna banka za trgovinu, obrt i industriju d.d. Zagreb. Određen je i upis podružnica, i to zadržanih od Centralne banke u Varaždinu, Mariboru, Karlovcu, Požegi, Novom Sadu, Krapini, Ivancu, Velikom Trgovištu i Klanjcu, a od Centralne eskomptne i mjenjačne banke podružnice u Slavonskom Brodu (Brodu na Savi) i Đakovu. Podružnice Centralne banke za trgovinu, obrt i industriju d.d. Zagreb bile su u Slavonskom Brodu, Đakovu, Ivancu, Karlovcu, Klanjcu, Koprivnici, Krapini, Mariboru, Novom Sadu, Požegi, Rumi, Varaždinu i Velikom Trgovištu. Godine 1925. u trgovački registar u Zagrebu upisana je likvidacija Centralne banke za trgovinu, obrt i industriju d.d. u Zagrebu, a Okružni sud za grad Zagreb objavio je 1948. njezino brisanje iz trgovačkoga registra. Likvidacija banke provedena je i dovršena u sklopu Prve hrvatske štedionice u Zagrebu kao njezina jedinoga vjerovnika. Usp. Lajnert, "Arhivistički prikaz," str. 606, 618-619; Ivica Halapir i Siniša Lajnert, "HRHDA-2111. Centralna banka za trgovinu, obrt i industriju d.d. Zagreb (1906-1948)," (sumarni inventar fonda, Hrvatski državni arhiv, Zagreb, 2019), str. 8-9.

72 HR-HDA-757. Plavšić, dosje o likvidaciji Balkanske banke d.d. (1922-1948), izvještaj izvanredne glavne skupštine Balkanske banke od 18. travnja 1925., izvještaj upravnoga odbora Balkanske banke od 7. travnja 1925. za izvanrednu glavnu skupštinu dioničara (kut. 59); dosje Balkanska banka d.d. u likvidaciji (prikaz sloma i razno) (kut. 5). 
Spomenimo da je prema sveukupnoj čistoj bilanci Balkanske banke od 31. prosinca 1923. dionička glavnica i dalje iznosila $18,750.000$ dinara, a čisti gubitak iznosio je 29,479.386,80 dinara. ${ }^{73}$

Upravni odbor Balkanske banke d.d. u Zagrebu objavio je 8. travnja 1925. u Narodnim novinama da je sazvana izvanredna glavna skupština na temu donošenja zaključka o likvidaciji banke te o izboru likvidacijskoga i nadzornoga odbora. ${ }^{74}$ Izvanredna glavna skupština održana je 18. travnja 1925. godine. Bilo je nazočno 22 dioničara, od kojih 17 osobno, i to: Dragica Ebrić, Mihajlo Ebrić, Matija Herceg, Franjo Ottenfels, Dušan Plavšić, Antun Gueratto, Branko Pešić, Dragan Novosel, Amon Rukavina, Albert Hertmann, Hertmann i Slavnić, Ljubomir Tomašić, Anđela Gregurić, Rudolf Kunz, Valerij Riesner, Alfred Peyer, Božidar Živoder, Zdenko Longhino, Engleska trgovinska banka, Rudolf Blis, Stjepan Posilović i Richard Neuman. Upravni odbor banke (Plavšić, Herceg, Rukavina, Riesner i Zlatarić) u svojem izvještaju od 7. travnja 1925. bio je mišljenja da su financijske poteškoće u koje je banka zapala bile isključivo posljedica nesretnih okolnosti te da bi u istoj situaciji stradao i znatno jači zavod. Osim toga, na propast banke utjecale su i političke prilike koje su onemogućile da se ona sanira poslovnim aranžmanom. Upravni je odbor konstatirao da u banci nije bilo nikakvih malverzacija ni zlouporaba. Od članova uprave nitko se nije zlonamjerno koristio imetkom banke niti je itko od uprave na teret banke podizao ikakve beneficije kojima bi bila oštećena njezina imovina. Nadzorni odbor (Rudolf Kunz, Dragan Novosel, Longhino) u svojem izvještaju od 10. travnja 1925., izrađenom za izvanrednu glavnu skupštinu dioničara, ustanovio je da je glavni uzrok poteškoća u koje je banka zapala bio taj što neki novčani zavodi nisu u pravo vrijeme dobavili kod njih kupljene devize za pokriće od banke prodanih čekova, uslijed čega je ona, budući da nije imala dovoljno raspoloživih financijskih sredstava, ostala u zaostatku sa svojim obvezama te došla u nemogućnost da honorira svoje izdane čekove. Nadzorni odbor tom je prilikom proučio i zapisnike sastavljene povodom nadzora komisije određene od strane Ministarstva financija, no iz tih zapisnika nije mogao ustanoviti da se je upravni odbor banke kod deviznoga poslovanja ogriješio o zakon ili predmetne uredbe. Pregledom financijskih knjiga i spisa banke, nadzorni je odbor konstatirao da su, s obzirom

\footnotetext{
73 HR-HDA-757. Plavšić, dosje Balkanska banka d.d. u likvidaciji (prikaz sloma i razno), sveukupna čista razmjera Balkanske banke za 31. prosinca 1923. (kut. 5). Po visini dioničke glavnice Balkanska banka spadala je u srednje novčarske zavode. Za usporedbu, Banka i štedionica d.d. Krapinske Toplice, kao mali novčarski zavod, imala je 31. prosinca 1923. dioničku glavnicu od samo 125.000 dinara i dobitak od 10.309,29 dinara, a Prva hrvatska štedionica, kao naš najstariji i najvažniji novčarski zavod (velebanka), imala je dioničku glavnicu od 75,000.000 dinara i dobitak od 20,599.158,02 dinara. Iste godine Hrvatska eskomptna banka d.d. Zagreb imala je dioničku glavnicu od čak 140,000.000 dinara i dobitak od 20,578.410,80 dinara. Usp. Poziv na XVI. redovitu glavnu skupštinu, NN 38/1924; Poziv na LXXVII. redovitu glavnu skupštinu, NN 44/1924; Poziv na 55. redovitu glavnu skupštinu, NN 49/1924.
}

74 Poziv na izvanrednu glavnu skupštinu, NN 82/1925. 
na negativnu novinsku kampanju, tiskovne vijesti o banci i njezinu poslovanju bile neosnovane i većim dijelom pretjerane te su u nastaloj krizi zavodu najviše štetile i priječile miran razvoj sanacije. Na glavnoj skupštini jednoglasno je prihvaćen zaključak o likvidaciji banke, a u likvidacijski odbor imenovani su: u ime vjerovničkoga odbora Stjepan Posilović, Rudolf Blis, Ante Makale i Edo Marković kao članovi, a Alfred Edward Eayres-Gardner i Dinko Ružić kao zamjenici; u ime garancijskoga konzorcija banke Matija Herceg i Ljubomir Tomašić kao članovi, a barun Amon Rukavina kao zamjenik. U nadzorni odbor imenovani su u ime vjerovničkoga odbora Lavoslav Henigsberg i Juraj Pećarević, a u ime garancijskoga konzorcija Franjo Ottenfels i Vinko Zlatarić. ${ }^{75}$ Temeljem navedenoga, Kr. sudbeni stol kao trgovački sud u Zagrebu dao je 23. travnja 1925. na znanje da je u trgovačkom registru za društvene tvrtke upisana likvidacija Balkanske banke d.d. u Zagrebu. ${ }^{76}$

Dana 19. siječnja 1928. Financijsko odjeljenje Generalne direkcije državnih željeznica Kraljevine SHS u Beogradu obavijestilo je Balkansku banku u likvidaciji da im je kod beogradskoga Trgovačkoga suda položena neto suma od 7,301.672,67 dinara na ime isplate računa Poduzeća Nikole Plavšića, odnosno Balkanske banke. ${ }^{77}$ Kao što je vidljivo, sudskim postupkom dioničari nisu uspjeli povratiti ni polovicu uloženih sredstava. Očito je da je Milan Stojadinović i na taj način odigrao negativnu ulogu u napadu na Dušana Plavšića, a samim time i na Balkansku banku. Nakon likvidacije banke, bogatstvo Dušana Plavšića počinje se topiti, a preko Balkanske banke povlači u propast i veći broj nekadašnjih hrvatskih veleposjednika plemića. ${ }^{78}$

U smislu Naredbe sa zakonskom snagom o otuđivanju i poslovanju privrednih poduzeća ${ }^{79}$ od 30. listopada 1940., te Uputa dioničarskim društvima i

\footnotetext{
75 HR-HDA-757. Plavšić, dosje o likvidaciji Balkanske banke d.d. (1922-1948), izvještaj izvanredne glavne skupštine Balkanske banke od 18. travnja 1925., izvještaj upravnoga odbora Balkanske banke od 7. travnja 1925. za izvanrednu glavnu skupštinu dioničara (kut. 59).

76 Upisi tvrdka, NN 102/1925. Kr. sudbeni stol kao trgovački sud u Zagrebu brisao je 24. rujna 1925. podružnicu u Beogradu Balkanske banke d.d. u likvidaciji, jer je sva njezina dugovanja i potraživanja preuzela centrala u Zagrebu. Usp. Upisi tvrtka, NN 247/1925.

77 HR-HDA-757. Plavšić, dosje o likvidaciji Balkanske banke d.d. (1922-1948), prijepis dopisa koji je 19. siječnja 1928. Generalna direkcija državnih željeznica u Beogradu poslala Balkanskoj banci u Zagrebu (kut. 59).

78 Usp. Kolar, "Buran život dr. Dušana Plavšića," str. 135; Mira Kolar-Dimitrijević, Povijest novca u Hrvatskoj od 1527. do 1941. godine (Zagreb: Hrvatska narodna banka, 2013), str. 147 i 152.

79 Temeljem navedene Naredbe, sva dionička društva sa sjedištem na području Banovine Hrvatske i imaoci dionica takvih društava trebali su u roku od 8 dana registrirati svoje dionice kod Odjela za obrt, industriju i trgovinu Banske vlasti. U tu svrhu kod navedenoga Odjela osnovan je katastar dionica. S neregistriranim dionicama imaoci do daljnjega nisu mogli obavljati svoja dioničarska prava. Usp. Naredba sa zakonskom snagom o otuđivanju i poslovanju privrednih poduzeća, NN 249/1940.
} 
imaocima dionica o dostavljanju podataka za katastar dionica ${ }^{80}$ od 31. listopada 1940., uprava Balkanske banke d.d. u likvidaciji Zagreb, Baruna Jelačića 3/IV, poslala je 8. studenoga 1940. Odjelu za obrt, industriju i trgovinu Banske vlasti Banovine Hrvatske u Zagrebu osnovne podatke o svojem zavodu. Banka je potvrdila da je zaključkom izvanredne glavne skupštine od 18. travnja 1925. stupila u likvidaciju. Predmet poslovanja bili su svi bankovni poslovi, ali je zavod poslije 18. travnja 1925. isključivo provađao svoju likvidaciju. Uplaćena dionička glavnica iznosila je 18,750.000 dinara podijeljena u 187.500 dionica po 100 dinara koje su glasile na donosioca. Zavod od zadnje glavne skupštine 18. travnja 1925. nije više održao ni jednu skupštinu dioničara. Balkanska banka imala je tada u svojem posjedu i vlasništvu 136.150 dionica, a ostatak od 41.350 dionica bio je u nepoznatim rukama. Likvidacija zavoda bila je dovršena, te se je tada pripremao izvještaj za Financijsku direkciju i Sudbeni stol u Zagrebu radi brisanja tvrtke u trgovačkom registru. Dionička glavnica bila je u cijelosti izgubljena, uslijed čega su dionice bile posve bezvrijedne. Članovi likvidacijskoga odbora banke bili su: 1. dr. Rudolf Blis, privatnik u Zagrebu; 2. dr. Dinko Ružić, državni nadodvjetnik u Zagrebu i barun Amon Rukavina, veleposjednik u Zagrebu, kao zamjenik. Članovi nadzornoga obora banke bili su: 1. dr. Juraj Pećarević, odvjetnik u Zagrebu; 2. barun Franjo Ottenfels, veleposjednik u Pregradi i Vinko Zlatarić, privatni činovnik u Beogradu. Uprava banke bila je mišljenja da prema tadašnjem stanju likvidacije i bezvrijednosti bančinih dionica nema svrhe te dionice unijeti u osnovani katastar dionica niti provesti njihovu registraciju. ${ }^{81}$

Dušan Plavšić obavijestio je 2. prosinca 1946. Ministarstvo financija Narodne Republike Hrvatske (NRH) u Zagrebu da Balkanska banka, koja je 1925. stupila u likvidaciju, pravno još postoji. Nalazila se je na Marulićevu trgu br. 17/II, kao podstanar kod bivše činovnice poslova likvidacije Štefanije Bernard, a poveći arhiv toga zavoda nalazio se je deponiran kod samoga Plavšića u Masarykovoj ulici br. 24/I. Balkanska banka do navedenoga datuma nije mogla dovršiti likvidaciju jer je imala s jedne strane dva potraživanja u Beogradu, koja se do tada nisu mogla naplatiti jer su dužnici također bili u likvidaciji, odnosno stečaju, i s druge strane, postojalo je još 17 neisplaćenih uložnih knjižnica sa sitnim ulozima, čiji se vlasnici nisu nikada javili. Pored navedenih vrlo dvojbenih

\footnotetext{
80 Temeljem navedenih Uputa, sva dionička društva u Banovini Hrvatskoj trebali su u podnesku, kojim su Odjelu za obrt, industriju i trgovinu Banske vlasti prijavljivali registraciju svojih dionica, dostaviti sljedeće podatke: naziv i sjedište društva, predmet poslovanja, iznos uplaćene dioničke glavnice te na koliko je dionica bila podijeljena, glase li dionice na donosioca ili na ime te podatke o dioničarima (ime i prezime, zanimanje, državljanstvo, narodnost, vjeroispovijest, prebivalište, ime oca i majke te njihovu vjeroispovijest i narodnost, broj dionica u njihovu posjedu s oznakom tekućih brojeva dionica). Usp. Upute dioničarskim društvima i imaocima dionica o dostavljanju podataka za katastar dionica, NN 249/1940.

81 HR-HDA-215, dosje Balkanska banka d.d. u likvidaciji Zagreb, dopis Balkanske banke upućen 8. studenoga 1940. Odjelu za obrt, industriju i trgovinu Banske vlasti Banovine Hrvatske u predmetu registracije njezinih dionica (kut. 270).
} 
potraživanja banka nije imala druge imovine, osim ostatka svojega inventara, koji je vođen u knjigama u vrijednosti od 2.000 dinara. Uslijed toga bila je likvidacija na mrtvoj točki, te je za njezino dovršenje i brisanje tvrtke trebalo donijeti odgovarajuće odluke. No, banka nije imala upravu, koja je takve odluke mogla donijeti. Plavšić podsjeća da su svojevremeno kao likvidatori postavljeni: Stjepan Posilović kao pročelnik te članovi Rudolf Blis, Matija Herceg, Ljubo Tomašić, Ante Makale i Edo Marković. Zamjenici su bili Dinko Ružić i Amon Rukavina. Tomašić se je zahvalio na članstvu prije mnogo godina jer se je preselio u Beograd, a ostali su članovi preminuli. Zamjenici pak, ako su i bili živi, imali su nepoznato boravište. Prema tome, Balkanska banka nije imala upravu ni činovništva jer je Štefanija Bernard, koja je cijelu likvidaciju radila za Likvidacijski odbor, razriješena dužnosti 30. lipnja 1943. zbog nedostatka sredstava za njezino plaćanje. Nakon toga postala je činovnica Saveza novčanih i osiguravajućih zavoda u likvidaciji u Zagrebu. Uz Dušana Plavšića, Štefanija Bernard bila je jedina upućena u cijelu problematiku likvidacije banke. Ona je provela sva potrebna knjiženja i zaključke, te i propisanu valorizaciju s bilancom za 31 . prosinca 1945. godine. Iz bilance za 31. prosinca 1945. vidljivo je da je nakon valorizacije banka imala dioničku glavnicu od 1,875.000 dinara, da iskazani gubitak iznosi 1,722.606,29 dinara, a gubitak od razlike u vezi sa zamjenom novca 46.527,98 dinara. Banka je na strani aktive (ukupno 116.896,54 dinara) imala gotovinu u blagajni od 1.838 dinara, dužnike u vrijednosti od 113.058,54 dinara (Beogradska komisiona banka u Beogradu, Sava Zan iz Alibunara, Sima Alkalay iz Beograda i Hrvatska udružena banka iz Zagreba) te inventar koji je po knjigama iznosio 2.000 dinara. Nasuprot toj aktivi, stanje pasive (11.030,81 dinara) bilo je sljedeće: ulozi obračunati u DFJ dinare ${ }^{82}$ iznosili su 10.989, 47 dinara te vjerovnici u vrijednosti od 41,34 dinara. Ako pasivu odbijemo od aktive dobijemo razliku od 105.865,73 dinara. Što se tiče dužnika banke, njihova naplata bila je dvojbena. Što se isplate 17 nerealiziranih uloga tiče, njihovi vlasnici nisu se javili ni na opetovane pozive u dnevnom tisku još od 1926. godine, pa je pretpostavljeno da se ni neće pojaviti. Jedina realna vrijednost koju je banka posjedovala bio je ostatak njezina inventara, koji je, iako je u knjigama vođen s 2.000 dinara, predstavljao prodajnu vrijednost od 10.400 dinara. Kada se rasproda, pokrili bi se tekući troškovi do brisanja tvrtke te za nagradu Štefaniji Bernard, koja je vodila poslovodstvo. Dušan Plavšić predložio je Ministarstvu financija NRH da se nave-

\footnotetext{
82 Zakonom o povlačenju i zamjeni okupacijskih novčanica od 5. travnja 1945. uvedena je nova novčana jedinica Demokratske Federativne Jugoslavije - dinar (din), koji se je dijelio na 100 para (p). Kao primjer usporedbe vrijednosti dinara DFJ u odnosu na druge valute navodim privremeni tečaj od 11. prosinca 1945.: 1 američki dolar $=50$ din, 1 kanadski dolar $=50$ din, 1 engleska funta $=200$ din, 1 rubalj SSSR $=5$ din, 1 švicarski franak $=10,70$ din, 1 francuski franak $=0,25$ din. Da bismo shvatili realnu vrijednost dinara te ju usporedili sa stvarnom vrijednošću kapitala banke, spomenimo da su na tjednom zagrebačkom sajmu održanom 18. srpnja 1945. cijene bile sljedeće: sijeno 9-11 dinara po kg, slama 7 dinara po kg, ogrjev 750-1.200 dinara po metru, buče 10 dinara, krumpir 12 dinara, luk 10 dinara, jabuke 12 dinara, kruške 18 dinara, mlijeko 12 dinara. Usp. Siniša Lajnert, "Senjska štedionica Senj (1873-1948)," Senjski zbornik 46 (2019): str. 290.
} 
deni zamjenici članova likvidacijskoga odbora Dinko Ružić i Amon Rukavina razriješe dužnosti te da se postavi novi likvidator, kojemu bi trebalo dati ovlast da otpiše navedena potraživanja kao nenaplativa i uloge, jer se ulagači nisu unatoč pozivu pojavili. Likvidator je također trebao rasprodati inventar te nakon isplate tekućih troškova i eventualne nagrade zaključiti likvidaciju, a po odobrenju konačnoga obračuna od strane nadležnoga ministarstva, tvrtku brisati. ${ }^{83}$

Ministarstvo financija NRH proslijedilo je 11. prosinca 1946. Ministarstvu financija Federativne Narodne Republike Jugoslavije (FNRJ) u Beogradu gore navedenu molbu Dušana Plavšića u predmetu revizije odobrenja za rad Balkanske banke, $s$ napomenom da se likvidacija treba samo dovršiti. U vezi s time, Ministarstvo financija NRH predložilo je likvidacijski odbor u sastavu: Milan Možina, činovnik toga Ministarstva, kao predstavnik Ministarstva financija FNRJ i predsjednik likvidacijskoga odbora, Stefanija Bernard, činovnica Saveza novčanih i osiguravajućih zavoda u likvidaciji u Zagrebu, Marulićev trg br. 17, kao predstavnica Balkanske banke d.d., te Dušan Plavšić iz Zagreba, kao predstavnik ulagača te banke. ${ }^{84}$

Temeljem rješenja Ministarstva financija FNRJ VII. br. 26801-46 od 9. siječnja 1947. određena je likvidacija Balkanske banke d.d. u likvidaciji u Zagrebu, te su potvrđeni predloženi članovi likvidacijskoga odbora. Likvidacija je trebala biti provedena po propisima Uredbe o reviziji dozvola za rad i likvidaciji privatnih kreditnih poduzeća ${ }^{85}$ i po propisima Pravilnika o postupku likvidacije privatnih kreditnih poduzeća. ${ }^{86}$ Vjerovnici i dužnici Balkanske banke u likvidaciji imali su pravo u roku od mjesec dana od dana objave odluke o likvidaciji u Narodnim novinama provjeriti svoje tražbine, odnosno dugove. Po izmaku toga roka knjiženja su smatrana vjerodostojnima. ${ }^{87}$

Okružni sud za grad Zagreb objavio je 21. ožujka 1947. u trgovačkom registru za društvene tvrtke da je upisana likvidacija Balkanske banke. Istovremeno su upisana i spomenuta tri člana likvidacijskoga odbora. ${ }^{88}$

Likvidacijski odbor Balkanske banke u Zagrebu, Masarykova br. 24/1, priopćio je 25. listopada 1947. Ministarstvu financija NRH da je njezina likvida-

83 HR-HDA-620. SLSP CNBJZ, 8.4. dosje Balkanska banka d.d. Zagreb, dopis Dušana Plavšića upućen 2. prosinca 1946. Ministarstvu financija NRH u Zagrebu, ur.br. 3838/1946. (kut. 187).

${ }^{84}$ HR-HDA-620. SLSP CNBJZ, 8.4. dosje Balkanska banka d.d. Zagreb, dopis Ministarstva financija NRH u Zagrebu upućen 11. prosinca 1946. Ministarstvu financija FNRJ u Beogradu pod br. 3838-VI1946. (kut. 187).

85 Uredba o reviziji dozvola za rad i likvidaciji privatnih kreditnih poduzeća, SL 51/1946.

86 Pravilnik o postupku likvidacije privatnih kreditnih poduzeća, SL 57/1946.

87 Likvidacija, NN 13/1947. Usp. HR-HDA-757. Plavšić, dosje o likvidaciji Balkanske banke d.d. (1922-1948), dopis Balkanske banke upućen 7. veljače 1947. Okružnomu narodnom sudu za grad Zagreb (kut. 59).

88 Likvidacije, NN 43/1947. 
cija završena. Završna bilanca iskazivala je u aktivi imovinu, koja se je sastojala od gotovine u blagajni od 8.170,16 dinara, a u pasivi nenamirene uloge, čiji se vlasnici nisu javili, u iznosu od 10.989,47 dinara. Dionička glavnica od 1,875.000 dinara bila je u cijelosti izgubljena, jer je gubitak iznosio 1,877.819,31 dinara. Dioničari za svoje dionice nisu mogli dobiti ništa. Kako je gotovina u blagajni od 8.170,16 dinara predstavljala cijelu raspoloživu bančinu imovinu, a nenamirene obveze 10.989,47 dinara, nenamireni ulagači mogli su se namiriti samo djelomično u razmjeru prema raspoloživoj gotovini. ${ }^{89}$

Na temelju rješenja Ministarstva financija NRH od 5. studenoga 1947., 90 likvidacijski odbor banke izvijestio je 8. travnja 1948. navedeno Ministarstvo da su o završetku likvidacije banke obavijestili nadležni Okružni sud za grad Zagreb u Zagrebu, te na temelju rješenja istoga br. Fi: 3089/33 od 10. ožujka 1948. izvršili sljedeće:

1. ostatak imovine Balkanske banke od 8.170,16 dinara položen je kod Glavne filijale Državne investicione banke FNRJ u Zagrebu; ${ }^{91}$

2. bančin arhiv predan je Okružnomu sudu za grad Zagreb radi pohrane. ${ }^{92}$

${ }^{89}$ HR-HDA-620. SLSP CNBJZ, 8.4. dosje Balkanska banka d.d. Zagreb, Izvještaj od 25. listopada 1947. o dokončanju likvidacije Balkanske banke (kut. 187).

90 Ministarstvo financija NRH odobrilo je svojim rješenjem br. 26892-I-1-47 od 5. studenoga 1947. podnesenu završnu likvidacijsku bilancu Balkanske banke za 25. listopada 1947., kao i prijedlog za isplatu vjerovnika. Usp. HR-HDA-620. SLSP CNBJZ, 8.4. dosje Balkanska banka d.d. Zagreb, rješenje Ministarstva financija NRH u Zagrebu upućeno 5. studenoga 1947. Balkanskoj banci (kut. 187).

91 Temeljem Pravilnika o postupku likvidacije privatnih kreditnih poduzeća od 16. prosinca 1947., čl. 17, iznos koji je preostao za podjelu dioničarima položio je likvidator iskazom Državnoj investicionoj banci kao sudski depozit i o tom obavijestio nadležni sud. Usp. Pravilnik o postupku likvidacije privatnih kreditnih poduzeća (pročišćeni tekst), SL 3/1948. Iznos od 8.170,16 dinara zaprimljen je kod Glavne filijale Državne investicione banke FNRJ u Zagrebu u korist računa Okružnoga suda za grad Zagreb pod naslovom: Imovina bivše Balkanske banke d.d. u Zagrebu. Usp. HR-HDA-757. Plavšić, dosje o likvidaciji Balkanske banke d.d. (1922-1948), dopis Balkanske banke upućen 8. travnja 1948. Glavnoj filijali u Zagrebu Državne investicione banke FNRJ (kut. 59). Državna investiciona banka FNRJ u Beogradu potječe od Uprave Fondova Kraljevine Srbije osnovane 1862., koja je 1922. preimenovana u Državna hipotekarna banka Kraljevine SHS. Banka je u periodu Kraljevine Jugoslavije u Hrvatskoj imala dvije glavne podružnice, u Zagrebu i Splitu. Tijekom Drugoga svjetskoga rata Državna hipotekarna banka Beograd nastavila je djelovati u Srbiji pod istim imenom, a u Nezavisnoj Državi Hrvatskoj 6. svibnja 1941. Zakonskom odredbom o osnivanju Državnog vjeresijskog zavoda, osnivan je istoimeni zavod sa sjedištem u Zagrebu. Zakonom o uređenju i djelovanju kreditnog sistema od 26. listopada 1945. Državna hipotekarna banka ponovo je nastavila svoj rad kao savezna banka. Između ostaloga, u čl. 17 navedenoga zakona propisano je da savezne kreditne ustanove (među koje je spadala i Državna hipotekarna banka) preuzimaju svoje podružnice koje su pod okupacijom bile odcijepljene od centrale. Temeljem čl. 11 Zakona o potvrdi i izmjenama i nadopunama zakona o uređenju i djelovanju kreditnoga sistema od 26. listopada 1945., Državna hipotekarna banka FNRJ Beograd promijenila je ime u Državna investiciona banka FNRJ Beograd. Podružnica u Zagrebu zvala se je Državna investiciona banka, Glavna filijala u Zagrebu. Usp. Lajnert, "Arhivistički prikaz,” str. 626-629.

92 Likvidatori banke Milan Možina i Dušan Plavšić dostavili su 8. travnja 1948. Okružnomu sudu za grad Zagreb u Zagrebu bančin arhiv radi pohrane: glavnu knjigu od osnutka banke do zaključne bilance na dan 25. listopada 1947., četiri knjige blagajne od srpnja 1923. do 25. listopada 1947., dvije knjige 
Likvidatori su zamolili Ministarstvo financija da izda nalog za brisanje tvrtke u trgovačkom registru te da članove likvidacijskoga odbora razriješi dužnosti. ${ }^{93}$

Temeljem navedenoga izvještaja likvidacijskoga odbora banke od 8. travnja 1948., Ministarstvo financija NRH predložilo je 12. travnja 1948. Okružnomu narodnomu sudu za grad Zagreb brisanje spomenute banke iz trgovačkoga registra, ${ }^{94}$ što je isti nedugo zatim i učinio. ${ }^{95}$

\section{Zaključak}

Cilj ovoga rada prikaz je ustroja, poslovanja i likvidacije Balkanske banke d.d. Zagreb. Poslove banke obavljali su glavna skupština dioničara, upravni odbor (ravnateljstvo) i nadzorno vijeće. Banka je osnovana 1922., da bi 1925. ušla u proces likvidacije, koja je formalno završena 1948. godine. Prvotni događaj nakon kojega je počelo urušavanje banke bio je imenovanje predsjednika Balkanske banke demokrata Dušana Plavšića pomoćnikom ministra financija Koste Kumanudija. Plavšić je počeo obavljati sve dolarske transakcije iz Blairova zajma za poboljšanje dinara. Nakon početnoga uspjeha, dinar se je za kratko vrijeme vratio na svoju staru vrijednost. Nekoliko mjeseci nakon što je Plavšić postao pomoćnik ministra, propala je koalicijska vlada, pa je iz Ministarstva financija uz Kumanudija morao otići i on. Za novoga ministra financija postavljen je radikal Milan Stojadinović. Plavšić je kritizirao njegovu financijsku politiku. Naravno, Stojadinović mu nije ostao dužan. Počeo je kontinuirano napadati Plavšića, što se je pokazalo pogubno po njega i po Balkansku banku. Istovremeno je i tisak Hrvatskoga bloka u Zagrebu napadao Plavšića i poslovanje Balkanske banke, ponekad i pretjerujući u tome. Banci zasigurno nije pomoglo ni to što su, sudeći prema dokumentima iz Plavšićeve rukopisne ostavštine, u njezinoj upravi sjedili

uloga od osnutka banke do završetka likvidacije, saldo konti dužnika s prijenosima od 1925. do zaključka likvidacije, saldo konti vjerovnika s prijenosima od 1925. do zaključka likvidacije, knjige računa gubitka i dobitka do zaključka likvidacije, primanote od 1923. do 1947., blagajničke arke i temeljnice od 1925. do 1947., sabirne arke blagajne i primanote od 1933. do 1947., korespondenciju od 1925. do završetka likvidacije, sanduk spisa o prinudnoj nagodbi, glavnoj skupštini o zaključku likvidacije, nagodbi s ulagačima, parnicom s državom glede potraživanja banke i o drugim važnim poslovima, knjigu dioničara i međutomnica, zapisnike staroga i novoga likvidacijskoga odbora te podneske Ministarstvu financija o provođenju i zaključku likvidacije. Usp. HR-HDA-757. Plavšić, dosje o likvidaciji Balkanske banke d.d. (1922-1948), dopis Balkanske banke upućen 8. travnja 1948. Okružnomu sudu za grad Zagreb i popis arhiva Balkanske banke od 25. listopada 1947. (kut. 59).

93 HR-HDA-757. Plavšić, dosje o likvidaciji Balkanske banke d.d. (1922-1948), dopis Balkanske banke upućen 8. travnja 1948. Ministarstvu financija NRH u Zagrebu (kut. 59).

94 HR-HDA-620. SLSP CNBJZ, 8.4. dosje Balkanska banka d.d. Zagreb, dopis Ministarstva financija NRH upućen 12. travnja 1948. Okružnomu narodnomu sudu u Zagrebu pod br. 6156-I-1-1948. (kut. 187).

95 Brisanja, NN 62/1948. 
Hrvati unitaristi. Sam Plavšić bio je pristaša unitarne jugoslavenske ideje. Pretpostavka je da je Stojadinović na svoj način odigrao negativnu ulogu i kada je država oduzela koncesiju tvrtki Nikole Plavšića za gradnju pruge Vardišste-Šargan, koji je posao banka kao partner financirala. Taj događaj predstavljao je presudan trenutak, jer je banci tada oduzeta zadnja nada da dođe do jedne od svojih najvećih tražbina za pokriće financijskoga manjka. Naravno, Balkanska banka velikim je dijelom i sama kriva za svoj krah. Iskoristila je nedostatak zakonske regulative o čekovima, pa je, očekujući brzu i veliku zaradu, naivno, brzopleto i nepromišljeno ušla u rizične i loše izvedene devizno čekovne transakcije, što se je pokazalo katastrofalno po nju. Rukovodstvo banke samo je priznalo da u državama zapadne Europe, gdje su postojali zakoni o poslovanju s čekovima takve manipulacije nisu bile dopuštene, a poslovanje s čekovima u Kraljevini SHS, gdje nije postojao zakon o čekovima, bilo je proizvoljno. U svakom slučaju, banka se kod toga deviznoga poslovanja nije ogriješila ni o jedan zakon ili predmetnu uredbu. Ne mora se ni reći da su banke kod kojih je Balkanska banka kupila devize za pokriće čekova koje je prodala samo iskoristile priliku da se riješe poslovnoga (vjerojatno i političkoga) protivnika, pa su oduljile s nabavom tih deviza, što je bilo dovoljno da Balkansku banku odvede u financijsku propast. Iako je likvidaciji Balkanske banke kumovao cijeli niz nesretnih okolnosti, te bi u istoj situaciji nastradao $\mathrm{i}$ mnogo jači zavod, nameće se zaključak da je, kao što je to često slučaj, na propast Balkanske banke velikim dijelom utjecala i politika. Plavšić se svojim političkim i gospodarskim aktivnostima zamjerio vodećim političkim strukturama u Zagrebu i Beogradu, kao centrima moći, kojima sasvim sigurno nije odgovarao jak Plavšić, a samim time i jaka Balkanska banka.

\section{POPIS IZVORA}

\section{Arhivsko gradivo}

Hrvatski državni arhiv

HR-HDA-152. Savska financijska direkcija (SFD).

HR-HDA-215. Ministarstvo državne riznice NDH (MDR NDH).

HR-HDA-620. Služba likvidacije starih poslova Centrale Narodne banke Jugoslavije u Zagrebu (SLSP CNBJZ).

HR-HDA-757. Obitelj Plavšić (Plavšić).

Državni arhiv Zagreb

HR-DAZG-1249. Balkanska banka d.d. Zagreb (BB/Z). 


\section{Službena glasila i tisak}

Narodne novine (Zagreb), 1922, 1924, 1925, 1940, 1947, 1948.

Službeni list (Beograd), 1946, 1948.

Službene novine (Beograd), 1919, 1920, 1922.

Hrvat (Zagreb), 1923.

Narodna straža (Šibenik), 1923.

Sbornik zakonah i naredabah valjanih za kraljevinu Hrvatsku i Slavoniju (Zagreb), 1877.

Tehnički list (Zagreb), 1924.

\section{Literatura}

Dretar, Milivoj. "Prilike u kotaru Ludbreg u poratnim godinama (1918.1925.)." U Varaždin i sjeverna Hrvatska u desetljeću nakon Velikog rata: Zbornik radova sa znanstvenog skupa održanog u Varaždinu 9. studenoga 2018. godine, ur. Stjepan Damjanović, Vladimir Huzjan, str. 201-225. Zagreb: Hrvatska akademija znanosti i umjetnosti, 2019.

Halapir, Ivica, Siniša Lajnert. "HR-HDA-2111. Centralna banka za trgovinu, obrt i industriju d.d. Zagreb (1906-1948)." Sumarni inventar, Hrvatski državni arhiv, Zagreb, 2019.

Hanel, Rudolf, ur. Compass: Finanzielles Jahrbuch 1923: Band II: Tschechoslovakei. Wien: Compassverlag, 1923.

Hanel, Rudolf, ur. Compass: Finanzielles Jahrbuch 1923: Band III: Jugoslavien, Ungarn. Zagreb: Compassverlag, 1923.

Hanel, Rudolf, ur. Compass: Finanzielles Jahrbuch 1925: Band III: Jugoslavien, Ungarn. Zagreb: Kompas, 1925.

"Hrvatski blok." U Hrvatska enciklopedija: 4: Fr-Ht, ur. Dalibor Brozović, str. 734. Zagreb: Leksikografski zavod Miroslav Krleža, 2002.

Klaić, Bratoljub. Rječnik stranih riječi: Tudice i posudenice. Zagreb: Nakladni zavod Matice hrvatske, 2001.

Kolar, Mira. "Buran život dr. Dušana Plavšića (1875-1965)." Osječki zbornik 24-25 (2001): str. 131-143.

Kolar-Dimitrijević, Mira. “O osnutku i radu Zagrebačke burze do 1945. godine.” Radovi 28 (1995): str. 190-211.

Kolar-Dimitrijević, Mira. Povijest novca u Hrvatskoj od 1527. do 1941. godine. Zagreb: Hrvatska narodna banka, 2013. 
Lajnert, Siniša. "Arhivistički prikaz sustava bankovno-novčarskih institucija u Hrvatskoj do likvidacije privatnih kreditnih poduzeća (1846-1949)." Doktorski rad, Sveučilište u Zagrebu, 2008.

Lajnert, Siniša. "Diskontna banka d.d. Zagreb (1920.-1948.)." Arhivski vjesnik 61 (2018): str. 157-182.

Lajnert, Siniša. "HR-HDA-541. Slavenska banka d.d. Zagreb (19111947).” Sumarni inventar, Hrvatski državni arhiv, Zagreb, 2011.

Lajnert, Siniša. "Jastrebarska dionička štedionica u Jastrebarskom: ustroj, djelovanje i likvidacija (1894-1948).” Arhivski vjesnik 58 (2015): str. 121-174.

Lajnert, Siniša. "Senjska štedionica Senj (1873-1948).” Senjski zbornik 46 (2019): str. 249-296.

Matković, Hrvoje. "Stjepan Radić i Hrvatski blok." Radovi 32-33 (2000): str. 267-276.

Mirosavljević, Ksenija. "AJ-65. Ministarstvo trgovine i industrije Kraljevine Jugoslavije (1918-1941).” Sumarno-analitički inventar, Arhiv Jugoslavije, Beograd, s. a.

Misailović, Ilija, Radovan Glibetić. Šarganska osmica: Železnička pruga Užice-Vardište. Beograd: SANU, 2010. der, 1934.

Narodna banka 1884.-1934. Beograd: Zavod za izradu novčanica Topči-

Tomašević, Jozo. Novac i kredit. Zagreb: vlastito izdanje, 1938.

Turkalj, Nikola. Gradnja željeznice Vardište-Užice. Tehnički list 6, br. 4 (15. veljače 1924): str. 45-50.

Winter, Marija. "Ludbreški grad i njegovi gospodari." Podravski zbornik 6 (1980): str. 357-369. 


\section{Summary}

\section{CONTRIBUTION TO THE STUDY OF THE BALKAN BANK LTD. IN ZAGREB (1922-1925/1948)}

The paper presents research results of the structure, business and liquidation of the Balkan Bank Ltd. in Zagreb from 1922 when it was founded, 1925 when it entered the liquidation process, until 1948 when its liquidation was formally finished. The bank had a branch in Belgrade. The bank's business had at first developed favourably, however, in August 1922 its president Dušan Plavšić took over the duty of the assistant finance minister. Since the government to which Plavšić belonged resigned in December 1922, a campaign in the press began due to political circumstances of that time and it was also aimed at the Balkan Bank. This gave the entire case a purely political connotation i.e. the bank's founders and managers were members of the Democratic Party, hence, Dušan Plavšić as its president was one of the prominent Party members. On the other hand, the next government was formed by Nikola Pašić and his Radicals and one of the latter, Milan Stojadinović, became a new finance minister. Plavšićs criticism of Stojadinovićs financial policy caused his fall into Stojadinovićs disfavour. After taking over his new duty, Stojadinović continually attacked Dušan Plavšić. The campaign in the press had severe consequences for the bank. The alarming news about the bank's inability to pay its obligations caused its investors to withdraw their money. Within several months the bank had to return from the current accounts circa 20.000,00 dinars to various creditors, mostly other banks. This demand compelled the bank's management to take drastic measures, since these demands put the entire business of the bank into a very difficult situation. The bank had to accelerate the turnover of its funds as much as possible, which could mostly be achieved in foreign exchange turnover. The bank went rather naïvely and precipitously into the badly executed transactions involving foreign currency cheques, which proved disastrous. Namely, the bank forced selling of the dollar cheques, securing them in foreign currency. However, even though the bank bought large foreign currency funds in cash from various financial institutes in Zagreb and Belgrade in order to secure the sold cheques, the institutes did not produce the bought funds in time. Hence, not having enough funds at its disposal the bank was unable to secure its issued cheques. This forced the bank to cease its activities concerning foreign currency. Naturally, the press denounced the bank for selling bounced cheques. Just when it was thought that things cannot get worse, the Ministry of Traffic revoked the concession of the construction firm of the Graduated Engineer Nikola Plavšić for constructing the VardišteŠargan railway, which was financed by the bank as a partner. The ensuing court battle did not enable the bank to regain even half of its invested funds, which took away its last hope to acquire larger financial funds. Its management had no alternative but to request the opening of the proceedings of agreement with cred- 
itors. The latter was adopted on 23 October 1924 and the decision of the Judicial Table as the agreement court in this issue was proclaimed on 10 November 1924. The agreement became final on 10 March 1925. Based on that agreement the Balkan Bank should have concluded its liquidation. The Extraordinary General Assembly on 18 April 1925 unanimously accepted the conclusion on the bank's liquidation. The bank legally existed until 1948 when, after its liquidation was formalised in practice, it was deleted from the commercial register of the County Court in Zagreb.

Keywords: Balkan Bank Ltd. in Zagreb; financial institute; banking business; Dušan Plavšić 